Max-Planck-Institut für demografische Forschung

Max Planck Institute for Demographic Research

Konrad-Zuse-Strasse 1 - D-18057 Rostock - GERMANY

Tel +49 (0) 3812081 - 0; Fax +49 (0) 3812081 - 202;

http://www.demogr.mpg.de

MPIDR WORKING PAPER WP 2003-021

JULY 2003

\title{
Family Policies and Low Fertility in Western Europe
}

Gerda Neyer (neyer@demogr.mpg.de)

This working paper has been approved for release by: Jan M. Hoem (hoem@demogr.mpg.de)

Head of the Laboratory of Contemporary European Fertility and Family Dynamics.

(C) Copyright is held by the authors.

Working papers of the Max Planck Institute for Demographic Research receive only limited review.

Views or opinions expressed in working papers are attributable to the authors and do not necessarily reflect those of the Institute. 


\title{
Family Policies and Low Fertility in Western Europe
}

\author{
Gerda Neyer \\ Max Planck Institute for Demographic Research \\ Konrad-Zuse-Strasse 1 \\ D-18057 Rostock
}

Views and opinions expressed in this paper are attributable to the author and do not necessarily reflect those of the Max Planck Institute for Demographic Research 


\begin{abstract}
This article examines current family policies in Western Europe against the backdrop of fertility decline in Europe. Its objective is to depict the nature of family policies from a cross-national perspective in order to illuminate potential relationships between them and demographic patterns. The article concentrates on those family policies that constitute the core of welfare-state policies related to childbearing and the rearing of children: Maternity policies, parental-leave policies, childcare services, and child benefits.
\end{abstract}

Keywords: family policies, fertility, Western Europe

Acknowledgment: The author would like to thank Jan Hoem for comments and AnnZofie Duvander and Harris Symeonidou for providing information on policies in their countries. 
1. Introduction 4

2. The development of fertility in Western Europe since the 1960s ...................................... 4

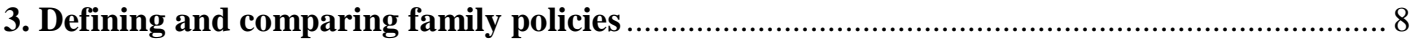

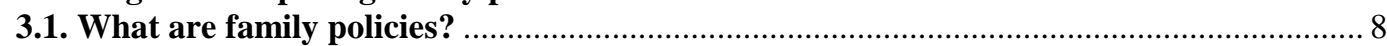

3.2. A framework for comparing family policies .......................................................... 10

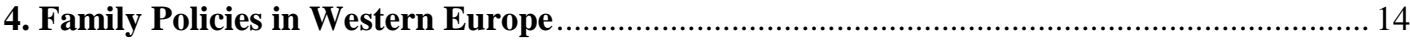

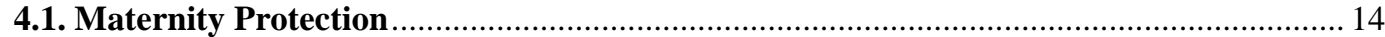

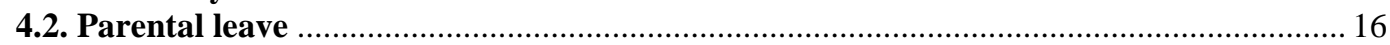

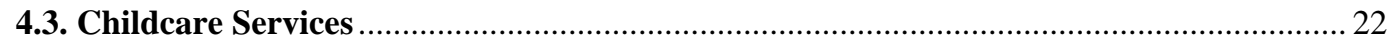

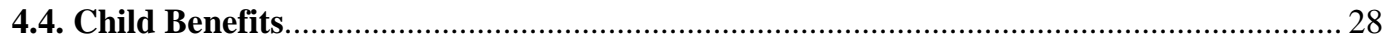

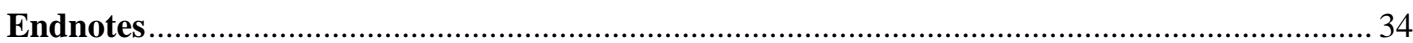




\section{Introduction}

Family policies have recently moved anew to the center of European politics, when the EU summit in Barcelona passed a recommendation that by 2010 member states should provide childcare to at least $33 \%$ children under age three and to at least $90 \%$ of children between age three and mandatory school age (European Council 2002, 12). Only a few years earlier the EU endorsed a directive that required member states to implement a minimal standard of parental leave in their national legislation. ${ }^{1}$ In both cases the purpose of the move was to raise female labor-force participation rates in EU member states by facilitating the reconciliation of family and worklife. The EU's efforts to set standards in employment-related family-policy measures must be viewed in light of the demographic challenges that Europe faces, in particular its low fertility.

Against the background of European fertility patterns, this article is devoted to an examination of current family policies across Europe. Our objective is to depict the development of family policies and to compare their nature in Europe from a crossnational perspective in order to illuminate potential relationships between them and demographic patterns. As a backdrop we provide an overview over the fertility decline. We then present approaches to the study of family policies in order to provide a framework for demographic analyses of policy effects. We focus on policies directed towards childbearing and child rearing. In conclusion we give an outlook over the options for European family policies and their potential demographic implications.

\section{The development of fertility in Western Europe since the 1960s}

All European countries have experienced a considerable decline of their fertility rates since the 1960s. Period total fertility rates have dropped below replacement levels and reached an average of 1.45 in the fifteen EU-countries in 1999. Eight out of fifteen Western European countries now experience a total fertility rate at or below 1.5. ${ }^{2}$ There are great variations among the countries in the timing and level at the onset of the decline as well as in the rate and the duration of the decline. Almost all European countries with continual democratic regimes after $1945^{3}$ experienced their major 
decline of fertility during the 1960s and 1970s. In the southern European countries Spain, Portugal, and Greece, the decline started somewhat later and proceeded with much faster pace. In the German-speaking countries Germany and Austria, the TFR continued to decline after 1980, although less rapidly than before; in Switzerland it has leveled off. In most of the Nordic countries (Norway, Denmark, and Finland), in France, and lately also in Belgium and the Netherlands, the TFR has risen slightly. Sweden and Italy seem to constitute the only exceptions to these general patterns of fertility development. In Sweden the TFR increased considerably during the late 1980s and early 1990s, but decreased rapidly in the 1990s. Italy has experienced a continuous and comparatively pronounced decline of the TFR since the middle of the 1970s and now has the lowest TFR in Europe (1.23 in 2000).

As a consequence of these different developments the duration of low fertility (TFR 1.5 or below) varies among countries. Persistently low-fertility countries are Austria, Germany (and in particular West Germany), Greece, Spain, and Italy. All of these countries have had a TFR of or below 1.5 since the mid 1980s; in West Germany the period of low fertility even started in the middle of the 1970s. Periods of low fertility also occurred in Denmark and the Netherlands during the 1980s as well as in Sweden at the end of the 1990s (Figures 1 to 4).

These developments led to a shift in the patterns of European fertility during the past decades. In the 1960s Europe's map of national fertility patterns was rather disperse, with marked differences in the fertility levels among countries that belonged to the same region. Fertility levels varied especially strongly among the countries of the North, of the South, and of the East, while the central European countries displayed a more homogenous pattern. At the turn of the $21^{\text {st }}$ century fertility levels have moved towards greater intraregional homogeneity. However, interregional variances have not diminished, but have remained stable or have even increased slightly (Figures 1 to 5 ). ${ }^{4}$ This move from national diversity towards intraregional homogeneity suggests that the TFR of countries in specific European regions converge, while the persistence of interregional diversity demonstrates that differences in country-level fertility patterns in Europe continue to persist (see also: Billari and Wilson 2001, Watkins 1990). Nowadays, the Nordic countries (except Sweden) as well as the group of France, Belgium, and the Netherlands constitute the 
two regions with the highest TFRs in Europe; the German-speaking and the southern European countries (except Portugal) are the ones with the lowest TFRs in Western Europe.

Researchers attribute the differences in the patterns of Western European fertility levels mainly to demographic and socio-economic factors. Demographically, the postponement of childbearing is regarded as one of the major driving forces of fertility development in Western Europe since the 1980s (Lesthaeghe and Moors 2000, 167). Between 1980 and the late 1990s, the mean age at first birth rose by about 2 to 3 years. Fertility of women below age 30 decreased while fertility of women above age 30 increased in all western European countries except in Greece, Spain, and Portugal. In these three countries the fertility of women aged 30 and above declined. The differences in the levels of the TFR in Europe thus to a large extent reflect the cross-national differences in the increase of fertility among women of "higher" ages, that is of women above age 30 (Lesthaeghe and Moors 2000, 167). This also accounts for the differences in completed cohort fertility levels across Europe (Figure 6). ${ }^{5}$

Socio-economically, the changes in European employment patterns, in particular the changes in women's labor-force participation, are regarded as key factors of fertility changes in Europe. Since the 1970s, women's employment has increased in all West-European countries. In most continental European countries female labor-force participation rates increased from just below 50\% percent in the mid 1970s to about 60\% percent in the mid 1990s (OECD 1998; Schmidt 2000, 271). In southern Europe (Italy, Greece, and Spain) female labor-force participation rates were about ten percentage points lower. In Scandinavia female labor-force participation rates were about fifteen to twenty percentage points higher than in continental Europe, ranging from about $65 \%$ in the mid 1970 s to $75 \%$ in the mid 1990s (OECD 1998; Schmidt 2000, 257). In cross-sectional comparison, the association between fertility and female labor-force participation reversed from negative to positive during this period. From a macro-level time-series perspective, however, the negative association did not reversed, but the magnitude and significance of the negative association decreased (Engelhardt, Kögel, and Prskawetz 2001). In the Scandinavian countries the negative correlation between female laborforce participation and TFR is now insignificant; in most continental European 
countries (West Germany, Austria, the Netherlands, and Great Britain) it has become weaker, but it is still significant. In the mediterranean countries the significantly negative relationship continues to persist (Kögel 2002).

The low fertility rates in Europe and the diverse pattern of development have given rise to concerns about the future imbalance of the population age structure, about social cohesion, and the sustainability of the European welfare-state systems. In most European countries, overt population-policy measures would meet resistance ${ }^{6}$ rather than acclamation among the population. By contrast, family-policy measures are regarded as a viable means of encouraging childbearing. But are family policies a sufficiently strong remedy against low fertility? The answer would require that we can use the results of systematic comparative research on the effects of family policies. Unfortunately such research is still largely missing. Apart from some early studies (Kamerman and Kahn 1978), family policies have only lately started to receive attention from the social sciences (Kamerman and Kahn 1991; Bradshaw et al 1993; Bahle 1995; Hantrais and Letablier 1996; Gauthier 1996a; Wennemo 1994; Gornick et al. 1997; Anttonen and Sipilä 1996). Only a few of these studies deal with the relationship between fertility and public policies from a comparative perspective (for exceptions, see Gauthier 1996a; 2001; Hantrais and Letablier 1996; Bahle 1995; Wennemo 1994; Hantrais 1997; Esping-Andersen 1999; 2002a). Demographic analyses of the effects of family policies on fertility are also rarely cross-national (Gauthier 1996; 2001; Gauthier and Hatzius 1997); the majority of the investigations is based on selected family-policy measures in individual countries (see Appendix).

Several reasons may account for this paucity. Undoubtedly there is a lack of suitable data. Ideally, such data should be longitudinal individual-level data. Data that meet these criteria are not yet widely available. The other major obstacle lies in the nature of family policies. They comprise a multitude of policies in many different areas, such as health-care and social-security policies, labor-market policies, housing policies, educational policies, taxation rules, family law, and so forth. Some familypolicy measures target family issues directly, others are part of policies that concern matters not primarily related to the family. Viewed together these policies may complement each other and form a coordinated or holistic set of family policies; or they may be disjoint elements with no apparent coherent policy direction. In some 
cases the policies may even offset or contradict each other. There are indications that the effectiveness of a particular family-policy measure depends on the degree to which it is aligned with other family-policy provisions. ${ }^{7}$ In order to assess the potential impact of family policies on fertility, it would be necessary to incorporate all family-policy provisions and pay attention to their configuration in the analysis. We do not know of any application of such a comprehensive approach, and using it goes well beyond the scope of this paper. We have more modest aspirations, and focus on specific family policies that are connected to childbearing and child rearing. In contrast to many other studies, which usually concentrate on the commonalities of national policies, we trace the differences and similarities in current provisions. This provides us with better insight toward understanding variations in the effects of family policies on fertility. To this purpose, we describe briefly some of the factors that have generated the variations in family-policy provisions in the next section and sketch a framework for comparison based on common dimensions of family policies.

\section{Defining and comparing family policies}

\subsection{What are family policies?}

Several researchers have pointed to the difficulties involved in conceptualizing and measuring family policies (Kamerman and Kahn 1978, 3f.; Bradshaw et al. 1993, 270; Hantrais 1994, 154; Anttonen and Sipilä 1996, 88, Bahle 1995, 17). One difficulty is that such policies usually relate to several aspects of family life. They regulate partnerships and parenthood, and they reflect the way in which states recognize obligations and responsibilities that result from these relationships. ${ }^{8}$ We concentrate on policies that target parenthood and in particular on policies that are most closely related to fertility: maternity policies, parental-leave policies, childcare services, and child benefits. The terminology for these policies varies from country to country, and several different terms are used in the literature as well. We therefore briefly define each of these measures:

Maternity policies: We use this term to cover employment-related measures to protect women when they are pregnant as well as mothers and their newly born children in the period right after childbirth. This includes protection against the exposure to potentially health-impairing substances or work environments. Their most 
important elements are compulsory or optional maternity leaves from employment before and/or after confinement, and maternity-leave benefits paid during such maternity leave.

Parental-leave policies: Parental leaves are leaves of absence from employment granted to parents in order that they can take care of their child for some time during the first few years of its life. Parental-leave benefits are benefits paid to a parent during such a leave. We only include leaves determined by law and not leaves that are part of individual work contracts or that have been arranged for employees on the basis of collective or company-based negotiations.

Childcare services: These comprise childcare provided by public or private institutions or child minders. Childcare may be offered by the state, the market, employers, or by non-profit institutions. Childcare services, as used in this paper, do not include childcare provided by parents or kin.

Child benefits: These are public transfers paid for children. We only consider direct transfers and do not include benefits granted as tax deductions or tax credits. ${ }^{9}$

These four policies - to which we limit the term "family policies" from now on - constitute the core of welfare-state policies related to childbearing and the rearing of (small) children. These policies are often backed by a series of different policy provisions that are incorporated in other welfare-state policies. Examples of such provisions are: child-rearing credits in the pension systems; the contribution-free inclusion of children in the health-care system; tax deduction for children; free transportation or transportation subsidies for families with children; housing subsidies for families with children (Bahle 1995, 19-20; Kamerman and Kahn 1978, 483ff.). Despite such common aspects there exist considerable inter-country differences in the range, the provisions, and the organization of these policies. Several reasons can be given for this: First, family policies bear different historical legacies. They have emerged out of different historical traditions and have taken different historical paths (Flora and Heidenheimer 1995; Pfau-Effinger 1999). As a consequence, in many countries, they have developed in an incoherent manner. They may not be consistent with the development and the orientation of other welfare-state policies and even be offset by other social-policy measures. 
Second, what we call family policies in the restricted sense represent a patchwork of policy objectives. The primary purpose for the implementation of specific family-policy measures has not always been connected to childbearing and child rearing as such. Intentions to reduce unemployment or poverty, to mark off boundaries of class or citizenship, to counterbalance population decline, to tackle labor shortage, to cut social expenditure, or to change or maintain gender relationships are some of the goals that have been associated with family-policy measures. As a consequence family policies may encompass inconsistent or even divergent aims.

\subsection{A framework for comparing family policies}

Although one needs to take account of the different paths and developments of family policies to understand their variations (Hemerijck and Schludi 2000; Schmidt 2000), we also need a framework based on common parameters in order to assess potential effects on fertility from a national and cross-national perspective. Since family policies are an integral part of welfare-state policies, we draw on the literature on European welfare-state regimes in reviewing and classifying family-policy set-ups in Europe.

Welfare-state research has shown that European countries can be grouped into distinct welfare-state regimes according to the intentions of their social policies and the principles on which they are based. Following Esping-Andersen's (1990; 1999) seminal work common classifications of welfare-state regimes distinguish between universalistic welfare states (the Nordic countries), conservative welfare states (continental European countries), liberal welfare states (Anglo-saxon countries), and although this is contested - Southern-European welfare states (Mediterranean countries).

Universalistic welfare states are characterized by welfare-state policies that are targeted at individual independence and social equality between individuals (not families). Public policies aim at covering social and employment-related risks and at upholding high living standards for everyone. Social benefits are granted on the basis of individual social-citizenship rights. Extended social services contribute to the defamilialization of welfare, that is to a reduction of the family's contribution to welfare. 
Conservative welfare states direct their welfare-state policies towards status maintenance and the preservation of traditional family forms. Social benefits correspond to work performance measured through the level and duration of contributions to social-security systems, or they depend on marriage. Conservative welfare states rely heavily on familialism, that is on the family as a provider of welfare.

Liberal welfare states encourage market-based individualism through minimal social benefits and though subsidizing private and marketized welfare schemes. Social benefits are usually means-tested and poverty-related. Social welfare depends on market provisions and on familialism.

The Southern European welfare states are often considered part of the conservative welfare-state regimes; but their stronger familialism merits that they are viewed as a separate welfare-state regime (Ferrera 1996; Esping-Andersen 1990, 23ff.; 1999, 62ff.). ${ }^{10}$

Esping-Andersen's typology is largely built on the principle of decommodification, that is on the extent to which a welfare state reduces a worker's dependence on the market by granting her the right to opt out of the labor market without severely endangering her livelihood (Esping-Andersen 1990, 22). Decommodification is coupled with de-familialization, that is the extent to which a welfare state frees the household from welfare obligations (Esping-Andersen 1999, 45).

Feminist welfare-state research has demonstrated that this classification of welfare-state regimes becomes more diverse if the family, family policies, and (female) commodification are taken into account. In contrast to Esping-Andersen (1999) who views the family as a unit, feminist research distinguishes between the two different relationships that may make up a family, namely partnership and parenthood. Welfare-state classifications deviate from Esping-Andersen's classification if cross-national comparisons $t$ focus on the way in which family policies regulate partnership and parenthood, on the availability of social care services, and on the gendering aspects of welfare-state policies (Gornick, Meyers, and Ross 1997; Meyers, Gornick, and Ross 1999; Anttonen and Sipilä 1996; Lewis 1992; Langan and Ostner 1991; Orloff 1993; Sainsbury 1994, 1999a; Hobson 1990; Daly 
2000; Daly and Lewis 2000; Lewis 1998; Knijn and Kremer 1997). Studying the impact of public policies ${ }^{11}$ on mothers' employment Gornick, Meyers, and Ross (1997, 65-66; and Meyers, Gornick, and Ross 1999, 119f.) find that Norway diverges from the other universalistic welfare states, and that the conservative welfare states of continental Europe show little commonality, with France and Germany contrasting particularly sharply. France forms a group with Belgium, Denmark, Finland, and Sweden. These countries offer reasonable support to mothers with children of all age groups, enabling them to enter and maintaining employment. Germany, the Netherlands, and Norway range average, while Italy offers high support for mothers of children from age 3 to school entry, but moderate for children below age three. In all of these countries, policies force mothers to reduce employment or exit from the labor market until the child can enter public childcare or school. In liberal welfare states (in Europe: the UK) policies are limited and the possibilities for mothers to maintain employment depend on their individual capacities.

Investigating cross-national variations of social care services Anttonen and Sipilä (1996) find similar cleavages among European welfare states. They distinguish between five different social care regimes in Europe ${ }^{12}$ : the Scandinavian model of public services, which provides universal coverage of care services to promote gender equality; the family care model of Southern Europe, with very limited supply of social care services (except for pre-school children in Italy); France and Belgium, which offer extensive day care and pre-school supply to support families with children (rather than autonomy for women as in the Scandinavian model), Germany and the Netherlands, which rely heavily on parental provision of care, and the British system, in which care services are limited, means-tested, and directed at "problem cases" (Anttonen and Sipilä 1996, 96-97).

Fraser (1997), Lewis (1992) and Langan/Ostner (1991) look at the impact of public policies regarding the gendered structure of care and employment within families. They thus put the emphasis on the effects of family policies on partnerships and on the division of work and care between women and men. Lewis and Langan/Ostner find that family policies in Europe support, moderate, or weaken the position of the male breadwinner. Taking account of the need to depart from the malebreadwinner model prevalent during the 1950s and 1960s, Fraser distinguishes 
between universal breadwinner policies, caregiver-parity policies, and earner-carer policies. Universal breadwinner policies focus on the market and on equal opportunities for women and men in the labor market. Such policies are inclined to subject women to adjust to male norms, and they do not assist women and families in their care obligations. Caregiver-parity policies give preference to the gendered division of employment and care, but they may smooth out resulting gender inequality by supporting caring labor through a system of social benefits and social credits. Earner-carer policies aim to enable both women and men to participate in caring and employment. These policies are directed towards changing gender relationships as well as changing labor relationships. As Sainsbury (1999b, 261f.) has shown, these policy strategies and their various combinations explain some of the discrepancies between European welfare-state regimes as well as some of the differences among the Scandinavian welfare states and among the continental European welfare states.

Feminist research has thus put the emphasis on the way in which family policies structure gender relations in the family and in society through the social organization of employment and care along gender lines. This approach has pointed out some important features of family policies that are relevant for an assessment of their potential effects on fertility: First, employment and care cannot be regarded as two separate spheres of life nor can family policies be regarded only with respect to their connection with family and care. Family policies intertwine employment and care in a way that reaches beyond the mere "reconciliation of family work and care". Family policies are determinants of women's “commodification" as well as of their "decommodification" (Orloff 1993, 318). The significance of family policies with respect to employment lies in the extent to which these policies ensure women's access to paid work irrespective of their caring tasks, just as much - or even more so - as it lies in the extent to which these policies allow women and men to abstain for employment for care reasons.

Second, since in all Western societies care is primarily a task assigned to women, a key aspect of family policies is the extent to which they relieve women of their care obligations. This involves the organization of care labor - that is the distribution of care between the state, the market, men, and women - as well as the existence of rights regarding care giving and care receiving (Knijn and Kremer 1997). 
The distribution of care labor between the public sector, the market, men, and women is vital for the extent to which policies contribute to alleviating women from care work and care responsibilities. The right to care giving and care receiving strengthens parents' power vis-à-vis the labor market (to have time off for care), vis-à-vis the state (to provide for the necessary care infrastructure), and - as regards women - vis-à-vis men (to resume their care obligations). Easing the burden of care also entails reducing the costs of care for women and for families through a redistribution of the costs between parents and society. The means of redistribution need to take into account potential impacts on employment and gender relations.

Thirdly, family policies are gender policies. Since the 1960s a key issue of family-related gender policies has been the extent to which family policies reduce women's dependence on a male breadwinner. This concerns the extent to which family policies allow women to maintain their own household by securing income for them and their family apart from a male breadwinner's income (Orloff 1993). In addition to granting women access to (decently paid) work this also implies that social benefits that compensate for income loss for caring mothers need to be sufficient to guarantee a livelihood. This is important not only because of the increasing percentage of lone mothers in Europe, but also because increasing instability of male employment careers make it more likely that women become family breadwinners.

By focusing on the different aims and outcomes that family policies may have with regard to shaping women's and men's life-course and their position within the family, the market, and society, this research offers a valuable framework for reviewing European family policies with the aim to trace their potential effects on fertility.

\section{Family Policies in Western Europe}

\subsection{Maternity Protection}

Maternity protection - and parental-leave policies are core elements of family policies. They are the oldest family-related welfare-state policies in Europe. Ever since the issue of caring for newly-born and small children emerged as a political topic in the late $19^{\text {th }}$ century, maternity protection and child-care leaves have been highly contested. Since the beginning, the question whether women should be allowed to 
interrupt their work to take care of their newly born children has been embedded in the discourse about female employment, gender differences, gender equality, labor protection, and labor regulation. At the turn to the $20^{\text {th }}$ century public debates about maternity and protective legislation for women were increasingly linked to discourses about the mothers' health, infant mortality, falling birthrates, population development, and the state of the nation. However, it was not until the second half of the $20^{\text {th }}$ century that the various issues became disentangled and that maternity protection and parental leave started to be regarded as two different sets of family policies.

Despite the similarities of their social, economic, and demographic situations concerning women and childbirth, European countries took quite different roads towards maternity protection and maternity leaves. The continental European countries, especially Switzerland, Austria, and Germany, introduced compulsory maternity and care leaves for working women, thereby polarizing the tension between paid labor and motherhood. France pursued a "politics of motherhood" that supports all women as mothers, makes motherhood compatible with wage labor, and thus assists women in reconciling employment and motherhood. In Scandinavia, maternity leaves and protective labor legislation for women only were met with greater caution. Such policies were regarded as procedures that might increase gender segregation in the labor market and undermine the work toward gender equality (Bock and Thane 1991; Koven and Michel 1993; Wikander, Harris, and Lewis 1995). ${ }^{13}$ Although international conventions ${ }^{14}$ passed since the early $20^{\text {th }}$ century have contributed to a convergence and harmonization of maternity legislation, remaining differences in the patterns of leaves and benefits still reflect the different approaches and historical paths to national maternity policies.

In continental Western Europe and the UK, the length of maternity leave varies between the recommended minimal length of 14 weeks in Germany and 20 weeks in Italy, with 16 to 18 weeks as the most common length. Special regulations may apply in the case of premature or multiple births. France grants a longer maternity leave to mothers of three and more children (26 weeks). In the Scandinavian countries, maternity leave is largely integrated into the optional and gender-neutral parentalleave scheme, although all countries reserve some part of the leave for mothers. In all 
countries maternity leave is a social right. Mothers on maternity leave are protected against dismissal and have the right to return to the same workplace.

In the majority of the countries, only mothers who have been in insured employment are entitled to maternity benefits for the time of maternity leave. The same applies to fathers in countries that offer paternal leave at the time of the birth of a child (usually short-term leaves). Universal rights to maternity benefits are granted to mothers in Finland, Norway, and partly in Sweden and Denmark (Missoc 2001; Moss and Deven 1999), but benefits are usually lower for mothers who have not been in employment prior to the birth of the child. A similar regulations exists in Austria, where since 2002 women without a prior employment record are entitled to a flat-rate benefit (as part of a universal parental-leave benefit). Some restrictions apply to foreign women. In almost all Western European countries, benefits reach $80 \%$ to $100 \%$ of former monthly wages for all or for part of the maternity leave.

The maternity provisions in Europe reflect the political intention to provide income and job security to mothers during pregnancy and after childbirth. National legislation varies with regard to whether the leave is compulsory or optional, in reflection of prevailing attitudes towards women and their employment. Aspects of health prevail over aspects of care for newly-born children. However, in some countries the maternity legislation pays attention to the child's need for care, in that it grants a father the right to paternity leave at the time of the birth of his child and/or the right to protected leave and benefit in case the mother is ill or dies during her maternity-leave period.

Table 1: Maternity provisions in Western

\subsection{Parental leave}

Among the family policies in Europe, parental leaves have emerged last and have been subject to the most extensive changes during the past two decades (Daly 2000). By granting mothers (in 1957) an option to take a 6-month unpaid leave after maternity leave Austria was the first country in Europe to establish parental leave. Many other countries introduced parental-leave schemes during the 1970s or the 1980s (Gauthier and Bortnik 2001). By the mid-1990s, the majority of the countries 
with parental-leave legislation offered some kind of payments during parental leave. Only Portugal, Spain, and Greece did not (Daly 1997, 140). With the implementation of the EC-Directive ${ }^{15}$ on parental leave, in 1998/1999, Belgium, Ireland, Luxembourg, and the $\mathrm{UK}^{16}$ were the last countries in Europe to establish parental-leave regulations (Falkner et al. 2002).

Governmental intentions of introducing and amending parental-leave regulations have varied considerably across countries and over time. In continental Europe, parental leave was usually regarded as an extension of maternity leave and thus exclusively reserved for mothers. Until the middle of the 1970s, it was primarily labor-market considerations, especially the shortage of labor, that led to the passing of parental-leave legislation. Since then - with the Nordic countries and foremost Sweden taking the lead - gender equality, care, and the reconciliation of work and family life have become the main issues of debate. It is this employment-care-gender nexus that makes parental-leave policies one of the most highly debated family policies in Europe.

European countries have implemented quite different parental-leave schemes. Rather short leaves - up to 6 months - are available in Greece, the UK, Denmark, and Portugal. Long leaves of two to three years are granted in Austria, Germany, France, and Spain. Leaves of more than half a year and less than two years are offered in Italy, Norway, and Sweden. Belgium, Finland, Norway, and Denmark have special leave regulations. Belgium offers an extended leave ("career break") as part of a labormarket policy that strives to integrate unemployed persons through employment rotation. Since 1985, Belgium has had the option of a career break or reduced working time available to all employees in the private sector for up to a lifetime total of five years, but dependent on the employer's consent. Payments are granted from six months up to one year if the parent on leave is replaced by an unemployed person. The leave-taker is protected against dismissal.

Finland, Norway, and Denmark offer extended leaves and benefits as an explicit alternative to the use of public childcare. Finland introduced a home-care allowance for all families with children under age three years in $1990 .{ }^{17}$ This benefit is available instead of a place in the public day-care system. Parents who use private childcare receive home-care allowance (in full or in part) to cover the costs of private childcare. 
Some municipalities pay supplements to the home-care allowance to reduce the demand for public childcare. Families with two or more children below school age receive additional siblings supplements. A means-tested addition to the home-care allowance is paid to families in which one parent takes care of the child herself or himself (Ilmakunnas 1997; Simonen and Kovalainen 1998). In 1999, Norway introduced a similar benefit, for parents with children aged 1 to 2 . The full payment is available for parents whose child(ren) do not use public childcare on a full-time basis (more than 32 hours per week). The full benefit is roughly equivalent to the state subsidy for a place in a day-care center. Parents whose child(ren) make use of public day-care services on a part-time basis receive a reduced benefit (Rønsen 2001). Denmark offers a childcare leave of 13 weeks for each parent until the child is 8 years old (26 weeks if the child is below age 1). ${ }^{18}$ Benefits are paid during this leave if the child does not attend public day care (for children below age three) or if the child is only in part-time day care (for children aged 3 to 6). The full benefit amounts to $60 \%$ of the maximum unemployment benefit (Rostgaard et al. 1999).

In all countries, except Portugal, parental leave is available only for parents. Portugal has instituted a leave for grandparents (Falkner et al. 2002). According to the EC-Directives, parents who take parental leave are protected against dismissal and have the right to return to the same workplace. However, the EC-Directive only requires countries to implement a three-month parental leave. National legislation with longer leaves may therefore not always grant such a comprehensive protection for the entire duration of the leave. In particular, the right to return to the same workplace may be softened to a right to return to "the same or an equivalent" workplace (Falkner et al. 2002). In addition, although parents have a right to parental leave, in some countries the employer may refuse to grant it at the time requested by the parent.

Benefits granted also vary considerably across countries. In the majority of countries parental leave is either unpaid or paid at a - usually rather low - flat rate. Income-related benefits that - calculated on the basis of the average wage of a production worker - allow mothers and fathers to maintain their standard of living are available only in Sweden, Norway, and Finland. Denmark pays benefits that range between flat-rate and employment-related benefits (at $60 \%$ percent of the maximum 
unemployment benefit). Special regulations regarding benefits apply to France, Germany, Finland, the Netherlands, Belgium, and Sweden. In France benefits are only available for parents of two or more children. In Germany benefits are means-tested. Finland pays additions to the home-care allowance according to the number of children. In Belgium and the Netherlands parental leave is unpaid, but trade-union agreements may provide for some pay. In Sweden, mothers who have their second or subsequent child within a certain period after their previous child receive benefits that are calculated on the basis of the income which they have had before they had their previous child ("speed premium"). This favors mothers who either interrupt their employment or reduce their working hours after the birth of a child. In countries in which benefits are provided, eligibility criteria regarding prior employment may apply.

In a number of countries, namely Belgium, Greece, Portugal, Austria, and Germany, there exist either two different parental-leave regulations for all or for special groups of workers, or regulations concerning parental leave and regulations concerning benefits do not match.

In Belgium, the right to (unpaid) parental leave and the right to a (paid) career break are mutually exclusive (Falkner et al. 2002). A similar situation exits in Portugal, where parents have a right to a three-month parental leave (with benefits and job-protection) or to an unpaid leave up to 24 months (with no job-protection). ${ }^{19}$ Austria pays childcare benefits up to the child's third birthday; but (job-protected) parental leave is available only until the child's second birthday. Three months of the parental leave may be taken until the child is 7 years old, but if taken after the child's third birthday, no benefits are paid. In Germany, the regulations are the reversed of the ones in Austria: Parental leave is available until the child's third birthday, benefits are only granted for 2 years.

The flexibility of the arrangements also differs from country to country. The leave is either granted right after maternity leave or around the birth of a child (Germany, France, Finland, Greece, Norway and Spain). Moderately flexible systems exist in Portugal and Belgium, (where the leave may be taken until the child is three or four years old), and in the Netherlands, Denmark, and Austria (where the leave or part of it may be used until the child is 7 or 8 years old). In the UK there are 
restrictions as to the maximum leave per year. The most flexible regulations exist in Sweden; there they largely allow parents to arrange their leave as needed to take care of their child.

Part-time regulations associated with the parental leave or while a child is under age three now exist all over Europe. In most cases, parental leave and part-time work may be combined. However, even though part-time work may be available, mothers and fathers may not have a right to it, but may need the consent of their employers. Benefits are usually reduced in case of part-time work, but they may be granted for a longer period of time. In some countries, like Belgium and Austria, the income loss due to the reduction of working time is not compensated. As with (full-time) parental leave, Sweden offers the most generous right-based regulations to reduce working time for care reasons until the child is eight.

In line with the EC Directive on parental leave, provisions that limited parental leave to mothers or made a father's claim to parental leave conditional on the mother's, were removed in all European countries. ${ }^{20}$ Parental leave is now available for each parent as an individual right. In most countries all parents have the same number of weeks or months of parental-leave entitlements. In some countries, part of the parental leave is reserved for the father, and the leave and benefits are lost if he does not make use of it.

The EC-Directive also required countries to implement the right to care breaks for urgent family reasons. Such care breaks are not limited to the care of children, but since children usually require care more often and unexpectedly (e.g.: due to sickness), they are an important element in parental rights to care. Since the Directive does not formulate requirements regarding the length or the remuneration of the care leave the regulations vary widely. They range from a three-day unremunerated leave per year, via specific short-term leaves (one to two weeks) per child and per year, to a very generous child-friendly care leave in Sweden (already enacted in 1980). In Sweden, childcare leave is granted for up to 120 days per year and child, 60 days of which may be used if the "usual carer" (that is the person or the center which usually care for the child) is unable to care for the child.

Table 2: Parental Leave in Western Europe (1999-2002) 
If we view the development and current regulations of parental leave in Europe from the perspective of their potential fertility impact, we recognize some distinct features: As Daly $(1997,140)$ noted, a lack of benefits or low and flat-rate benefits are "quite unusual" within earnings-related benefit systems. We may add that granting benefits and leaves to people for abstaining from using public services is also quite unusual within welfare-state systems in which benefits generally compensate for the loss or lack of income. On the other hand, we also observe that parental-leave systems have been expanded to include all employees. Likewise, the duration of the leave and benefits have been extended in most countries. This is also quite remarkable, since across Europe, entitlements to other welfare-state benefits have been tightened and labor legislation has loosened employees' rights.

Furthermore, entitlement to parental leave has become a social right for both mothers and fathers. Fathers' right to parental leave may not have an immediate implication for the gendered structure of parental leave, as the rates of fathers' uptake of parental leave in countries with some tradition of fathers' leaves show. ${ }^{21}$ In almost all countries, the levels of parental-leave benefits, the income gaps between women and men, and gender norms regarding employment and care pose obstacles to radical behavioral changes. Only Sweden, Denmark, Norway, and to a lesser extent Finland, have geared their labor-market, gender, and care policies to reducing gender inequality in employment, income, and care (Hernes 1987; Bergqvist et al. 1999). It is in these countries that fathers seem to be more prone to take at least some parental leave. However, in all countries the existence of equal rights to care leave is an important step towards changes in the family and in the employment sphere.

The move towards parental leaves across Europe indicates the political recognition of care needs, but also the recognition of the incompatibility of employment and care. As we have shown above, the strategies of the different countries to solve this conflict vary considerably, as do their realizations. Nevertheless, some similarities in policy setups are identifiable. In the Southern European countries and the UK, parental leave is least developed. Leaves are usually unpaid and although some countries have had parental leave for quite some time, it was not an idea inherent in the legislation of these countries (Falkner et al. 2002). The 
continental European welfare states pursue very different policy intentions. Germany and Austria both encourage mothers to exits from the labor market. In Germany, the policy is based on the assumption that a male breadwinner supports mother and child. This brings Germany closer to the Southern European countries in principle. Austria's complicated regulations regarding the upkeep of employment underline the policy intentions to value mothers' care work more than their employment, although the historically high rates of single mothers have led to less "male-breadwinner"-centered policy setups than in Germany. Belgium, France, and lately also the Netherlands put the emphasis on mothers' employment. The Netherlands encourages part-time work ${ }^{22}$ rather than a complete interruption of employment. France and Belgium support mothers' return to work, but have some options for longer retreats from the labor market. Among the Nordic countries, Sweden's and Denmark's parental-leave regulations are clearly oriented towards the employment of both parents. Sweden's policy accentuates parents' flexibility in organizing care and employment as well as the equal sharing of parental leaves among mothers and fathers. The Danish parentalleave regulations match the Danish policy of motivating early returns to employment through comparatively low benefits and - as we will see later - extensive public provisions of childcare.

\subsection{Childcare Services}

Public childcare services have emerged from the state's and society's concern for orphans and unattended children of lone and working mothers at the beginning of industrialization. During the $19^{\text {th }}$ and early $20^{\text {th }}$ century the main objective of public childcare shifted from charity to education. Childcare institutions were no longer to provide merely day care for poor children of working mothers, but to offer pre-school education to children of the lower classes. The aim was to promote children's social and individual development. The shift in the intent of public childcare was paralleled by a movement from private and church-based childcare programs to an increasing involvement of public authorities in supporting or providing childcare and pre-school education.

The Catholic countries of continental Western Europe (namely Belgium, France, Italy, and Austria), as well as the Netherlands and Great Britain were the 
forerunners in establishing institutional childcare in Europe. By 1920 they had already established a net of day nurseries, kindergartens, and pre-schools, with attendance rates of children aged 3-5 ranging up to 66\% (Bahle 1995, 102; Kamerman 2000, 3). At the end of the Second World War these Catholic countries and the Netherlands still offered the most extensive coverage of public childcare in Europe. ${ }^{23}$ But the various countries pursued very different childcare policies thereafter.

Belgium and France continued to expand their kindergarten system, reaching almost universal coverage for their 3-5 year olds in 1970. Since the 1970s they also invested in day care for children below age three In the Netherlands, public childcare was not promoted until the early 1990s when governmental initiatives opted for an expansion of childcare facilities on the basis of a "mixed economy", with services offered through public and private (marketized) institutions, as well as through publicly subsidized employer-provided childcare (Knijn 1998, 91f.; Bussemaker 1998; Hemerijck et al. 2000, 198ff.). ${ }^{24}$

Great Britain, Germany, and Austria pursued a policy that supported private care by mothers over universal public childcare for pre-school children (Ostner 1994, 45; Moeller 1993; Land and Lewis 1998). ${ }^{25}$ Recent initiatives have only partly departed from this orientation. In 1997 Great Britain launched efforts to stimulate the expansion of childcare and of pre-school education by replacing the previous voucher system by a childcare tax credit (Land and Lewis 1998; OECD 2001, 179). As a corollary to an amendment of abortion legislation Germany enacted legislation in 1996 that grants children aged three to six the right to a place in day care. In Austria, a short-term governmental initiative to provide extra funding for childcare led to a moderate increase in available childcare in the late 1990s (mostly in kindergartens and to a lesser extent in nurseries), but since 2000 policies have again focused on encouraging family care, particularly for the under threes.

Before the 1960s public childcare services in the Scandinavian countries lagged behind the continental ones. It was not until the late $1960 \mathrm{~s}^{26}$ and early $1970 \mathrm{~s}$ that the Scandinavian countries started to develop their public childcare services. Thereafter they expanded their systems far faster than the rest of the European countries. The vast expansion was brought about by major changes in the perception and purpose of public childcare. Day care was no longer regarded as an issue of welfare or education, 
but as a means of supporting women's participation in the labor force and reducing labor shortage (Sipilä et al. 1997, 33ff.) In the middle of the 1970s, childcare became part of the Scandinavian countries' policies towards universal care services, social and gender equality, and citizen's (children's) social rights. Legislation obliged local governments to create daycare places or supported them in the development of childcare facilities (Sipilä et al. 1997; Waerness 1998; Simonen and Kovalainen 1998; Szebehely 1998; Borchorst 2002). Contrary to most continental European countries, the Scandinavian countries aimed to provide childcare for children of all ages, including school-aged children. In the 1990s Finland and Norway have encouraged private solutions of childcare via a home-care allowance (Finland) or cash-for-care incentives (Norway) (Waerness 1998; Simonen and Kovalainen 1998; Borchorst 2002; Leira 2002, 113ff.). However, these supports for family or private care of children did not replace the children's right to a public daycare place.

From an organizational point of view, the state is the main suppliers of childcare in Europe, either through maintaining a major part of childcare institutions or through supporting childcare services by financing childcare providers (see below). The state's involvement in offering childcare services outside the children's home varies across Europe and within countries. In many countries, in particular in the Catholic ones, the Church is still a significant provider of institutional childcare, even though its contribution to childcare supply has diminished over the past forty years. In some countries, like the United Kingdom, Western Germany, and the Netherlands, nonprofit organizations have played a considerable role in offering childcare services for children of all age groups. In the Netherlands, the employers have come to play the major role as suppliers of childcare (Hemerijck 2000, 198ff.). In many other countries, voluntary and private organizations are particularly important in furnishing childcare for children below age three. In some countries various child-minder schemes substitute partly for institutional care. During the past decade, due to welfare-state restructuring and policy shifts from care to cash, voluntary and private organizations as well as child-minders have gained in importance as suppliers of childcare.

Administratively, sometimes also financially and legally, the responsibility for the provision of institutionalized public childcare usually lies with municipality or the 
region. This applies particularly to Germany, Austria, Italy, Denmark, and Sweden. While the latter two countries mandate municipalities to offer childcare services, and thus guarantee institutional care for every child, the others do not. This leads to great regional differences in the availability, the organization (e.g. opening hours), and the cost of childcare in these countries. The same applies in countries in which private institutions or child-minders play a considerable part in childcare system.

Table 3: Children in publicly funded childcare in Europe

The enrolment of children in childcare facilities varies considerably across Europe. Table 3 gives the figures for the mid-1990s and the late 1990s. Although strict comparison is problematic due to data collection and calculation methods ${ }^{27}$, the figures reflect the pattern of national childcare coverage in Europe. As far as children under age three are concerned, the Scandinavian countries, Belgium, and France offer comparatively widespread public childcare. Attendance rates are high by European standards. The Nordic countries, Belgium, and France are also the countries in Europe that have made each child's right to a public childcare place statutory even for the under-three's. In all other countries care for children below age three largely needs to be arranged privately. Finland is a case of its own. Although the figures for the middle of the 1990s show relatively high coverage in childcare for the under-threes, rates dropped until the late 1990s due to the high take-up rates of the home-care allowance and the high unemployment during the early 1990s. (Illmakunas 1997; Anttonen/Sipilä 1996; Sipilä 1997, Appendix). With the improving economic situation in the second half of the 1990s the number of under-three-year-old children in daycare increased again (Anttonen 2001, 149f.).

For children aged three up to mandatory school age (usually six), it is more common to attend institutional childcare. Most countries also guarantee a childcare place to children in this age group, though - as we will see below - not always on a full-time basis. In the middle of the 1990s, the participation rates for these children varied between $48 \%$ in Portugal and $99 \%$ in France. By the end of the 1990s coverage rates for almost all countries were beyond $75 \%$, with the majority of countries reporting attendance rates of $80 \%$ or more. Within this age group attendance rates increase with children approaching school entry. In many countries participation rates 
drop significantly once children have started to go to school. Only Denmark, Finland, France, Sweden, and to a lesser extent Norway and East Germany offer after-school care.

In Germany, the Netherlands, Austria, and the UK institutional care is to a large extent only provided on a part-time basis, even for children aged three to six. A German survey of 1992, for example, revealed that $57 \%$ of the children in a kindergarten (aged 3 to 6) in East Germany attended it full-time compared to only 7\% in West Germany (Ostner 1998, 130). In Austria, 22\% of all kindergartens in 1997 were open only half-day; $11 \%$ closed at lunchtime (Neyer, forthcoming). Average attendance rates in the Netherlands amount to 14.6 hours per week, compared to 28.2 hours per week in Sweden (in both cases: for children 0 to 12; The Clearinghouse 2000, Table 1.24).

If we look at childcare provisions from a comparative and a demographic perspective, we encounter a divide between the Scandinavian countries and the French-speaking countries on the one side, and the other continental European countries on the other side. In the Scandinavian countries, Belgium, and France childcare policy is directed towards an encompassing system of childcare for children of all age groups. Coverage is high for all age groups and backed by social rights to childcare. However, administratively and organizationally, the countries differ. In Belgium childcare is mainly based on a combination of public provisions of childcare and childcare services at home by independent carers who are often subsidized by government (Bussemaker and van Kersbergen 1999, 37). The Scandinavian countries have largely relied on public childcare, developed as part of their welfare-state services. Finland and Norway have started to deviate from this model by subsidizing private childcare and encouraging care of children through mothers (and fathers). Denmark and Sweden remain attached to their employment-oriented and stateprovided scheme of childcare. France has established a diversified system of different care options, including various public provisions as well as support for registered childminders and tax deduction for the use of private childminders.

While researchers embrace public childcare provisions as a means of supporting mothers and families, they are divided in their opinion about the impact of the subsidized privatization of childcare. These policies are usually argued for as 
increasing parents' choices of childcare. However, choices seem not to be equally distributed. Martin et al $(1998,151 f$.) argue with reference to France that this system offers full-range choices only to well-off families in metropolitan areas. For lowincome families, families with several children, lone mothers, and mothers in rural areas the childcare problem continues to persist. Similar concerns have been voiced by researchers for Scandinavia (Illmakunas 1997). The cash-for-care systems in France and in some Scandinavian countries have contributed to an increased gender division of caring work and a decrease of women's re-entry into the labor market after childbearing, because it is usually the mothers who withdraw from the labor force to take care of the child(ren) (Leira 2002). These reports must be read in the light of the fact that France as well as Finland and Norway have started to subsidize private (home or purchased) care from a very high level of public childcare coverage and well-developed system of public childcare

The childcare situation and the childcare policies of the Mediterranean, the German, and the English-speaking countries differ clearly from the ones of the Scandinavian and French-speaking countries. They have a very low number of publicly funded childcare for children under the age of three. Childcare for this age group is primarily regarded as a parental or family matter. Except for the Netherlands, which has successfully initiated a childcare stimulation program also directed at this age group, the attendance rates for children below age three have remained stagnantly low in the other countries.

For children between three and school-entry age the countries' policies are rather heterogeneous. Italy has long pursued a policy of universal access to public childcare for pre-school children (Della Sala 2002) and has one of the highest coverage rates in Europe. Spain regards pre-school childcare as a part of education, and provides an increasing number of places in public pre-schools (Valiente 2002). The UK, long viewing childcare as a private matter, has taken steps to enlarge its childcare services via the private and voluntary sectors (Randall 2002). Germany and Austria both take an ambivalent position towards childcare. They attempt to offer a place to every child (Germany) or to every child that needs public childcare (Austria), but they still retain their principle of subsidiarity. This means that in these countries, 
institutional care is directed at supplementing family care rather than offering an alternative to care provided or arranged by the parents.

In all "low-provision countries" childcare policies and childcare systems are in a state of recasting. There seems to be a general consensus about the need to expand public childcare services. At the same time childcare services are being decentralized, marketized, or moved to private initiatives. Given the fact that these changes start from a far lower level of childcare coverage than in the Scandinavian countries, in France, and in Belgium, this policy could increase the social and economic cleavages in accessibility and affordability of childcare among families.

\subsection{Child Benefits}

Child-benefit systems emerged out of a wide range of policy intentions. Some early schemes were directed towards specific groups of families in needs, such as widows with children, divorced or single mothers. Others granted benefits to orphans. After the Great War several countries introduced nutrition subsidies payable to children during the post-war years to alleviate poverty and malnutrition. In the period between the two World Wars almost all European countries introduced or maintained a system of family supplements. Family supplements were paid to workers with children to counter rising prices and fight economic hardship. In many countries only workers of specific industries and civil servants were entitled to family supplements. Most of the supplement arrangements lasted for only a few years, but they marked an important step in direction of the codification of monetary child-support schemes (Bahle 1995, 53ff.).

The majority of child-benefit systems in Europe that may be conceived as childsupport systems rather than as poverty- or needs-related systems were established after World War II. Only France and Belgium had institutionalized child-benefits systems prior to World War II that continued after 1945. In France the introduction of child-cash benefits was the outcome of a long struggle in which nationalistic, pronatalist, Catholic, and feminist groups joint forces in their request for governmental support for families (Offen 1991; Pedersen 1993; Cova 1991). The cash benefits were employment-based, directed towards large families and paid to the father, with supplements paid to mothers of large families as a "mother's wage" (Offen 1991, 
150). Belgium has paid child benefits to the mother ever since child-benefit schemes were introduced. The German speaking countries and the Netherlands re-introduced family benefits after World War II as compensation for wage restraints (Moeller 1993). The benefits were paid to male wage earners with several children. Italy and Spain also established child-benefits schemes that were targeted to male workers. The Scandinavian countries and Great Britain opted for universalistic forms of child benefits payable to mothers. In almost all countries child-benefits were first only paid to families with several children (Wennemo 1994, 62-64, 131ff.).

By 1985 most countries with previously employment-based child-benefit systems had switched to universal cash benefits, and in the majority of countries (7 out of 13) the mother received the benefit (Wennemo 1994, 64-67, 84). In addition, between the 1950s and the 1980s almost all countries amended their systems to make families eligible for child benefits independent of the number of children, the family income, or the family status.

As a consequence, in 2001 only 5 Western European countries tie the claim to child benefits to employment or employment-based insurance, namely the Southern European countries and Belgium. The Southern European countries additionally means-test their child benefits, granting child benefits only to families whose yearly income does not exceed a certain amount. Italy further requests that $70 \%$ of the annual earnings come from dependent work; Greece requires 50 days of insured employment during the year prior to the claim. Restrictions of beneficiaries also apply to France, where only families with two or more children receive child benefits. In all other countries all families with children are entitled to child benefits. Child benefits are thus the family-policy measure that is most widely governed by the principle of social rights.

Despite the fact that almost all child-benefit systems in Europe grant transfer payments to each child, only Norway treats each child equally. In all other countries the amount of benefit paid per child depends on the number of children in the family and/or their age. Several countries changed their system of benefit allocation according to age and/or number of children over the years. All countries, except Denmark, Norway, and Spain, now endorse a system by which the level of benefit per child depends on the number of children in the family. In general the benefit level 
increases with the number of children. Only in the United Kingdom is the benefit level lower for the second and all subsequent children. Sweden pays the same amount of benefit for the first two children and a higher benefit for the third and subsequent children. Germany follows a similar principle by spending more on the fourth and subsequent children.

Six countries pay different amounts of benefits dependent on the age of the child, three in addition to the different rates paid according to the number of children. The age ranges vary considerably. Portugal differentiates between children below 12 months and above 12 months; Norway below age 3 and above; Denmark sets the age limits at 3, 7 and 18; the Netherlands ${ }^{28}$ at 5, 11, and 17; Belgium ${ }^{29}$ at 6, 12, and 18; Austria at 10, 19, and 27; and France at 11 and 16 (Missoc 2001). In Portugal, Denmark, and Norway the benefit level decreases with the age of the child; in Austria, Belgium, France, and the Netherlands the level increases. Many countries pay additional benefits for handicapped children.

These different allocations of benefit levels according to the number of children and/or their age reflect the different principles behind the family support systems. Countries that scale their benefits according to the number of children seek to support families with several children more than families with only one child. These support policies are less inspired by pro-natalist intentions than by aims to prevent poverty or to maintain status levels. Countries which grade their child benefits by the age of the child assume that children of different ages incur different costs to their parents. But only three countries account for the fact that small children might cost more, if potential costs of childcare are included in the calculation.

Table 4: Child benefits in Europe 2000-2002

Child benefits are regarded as public compensation for the costs of children. However, Esping-Andersen (2002b, 53, Table 2.7) shows that from the mid-1980s to the mid-1990s the increase in social transfers to families with children in several European countries did not necessarily lead to an increase in their disposable income. Esping-Andersen even concludes that "the income position of families with children continues to decline in many countries regardless of a rise in per child transfer" 
(Esping-Andersen 2002b, 52). He further shows that although child benefits are still an important part of family support in Europe, the key factor to family well-being is mothers' employment (Esping-Andersen 2002b, 58).

\section{Family policies - a remedy against low fertility?}

If we view the development and current provisions of family policies from the perspective of their relation to fertility, some features are striking. There is considerable cross-national variation in the provisions and the modalities of family policies. This makes it difficult to investigate the effects of family policies on individual childbearing behavior in a comparative mode. Fortunately some countries share similar fertility developments as well as common aspects of family-policy orientation and family-policy systems. There is a clear divide between the Northern European countries, the Southern European countries, the French-speaking, and the German-speaking countries.

Family policies in the Scandinavian countries are oriented towards three goals: facilitating mothers' employment, alleviating mothers of their care work, and changing gender relations in care and employment. Public childcare for children of all age groups is widely available at comparatively low costs (Esping-Andersen 1999, 66). Access to childcare is guaranteed as a social right of children to a (full-time) place in public childcare. Parental leave is regulated in a way that allows parents to take care of their children without impairing their living standard or their employment. On the whole, the support of families is based on providing social services rather than cash benefits. Nevertheless all Scandinavian countries have increased their social transfers to families during the past decades (Esping-Andersen 2002b, 53). This has partly coincided with a shift of public policies towards subsidizing family care of children. Although Finland and Norway have relaxed their employment and gender-equality orientation in their family-policy schemes by introducing home-based care allowances, they have not diminished parents' and children's right to a place in public childcare.

In the Southern European countries, family policies related to childbearing and child rearing are not very developed. Public provision of childcare for the under- 
threes is rare, as is childcare for older children (with the exception of Italy), and childcare costs are comparatively high (Esping-Andersen 1999, 66). Parental leave is unpaid. Child benefits are not universally available and extremely low by European standards (Esping-Andersen 2002b, 62). In addition, these countries lack labor-market policies that support (young) women's and men's employment, and they expose young families to both employment and care risks.

Family policies in the other Continental European countries range between the Scandinavian schemes and the Southern European schemes. The French-speaking countries (France and Belgium) pursue a policy that supports mother's employment. Both countries have well-developed systems of public or financially supported childcare, but they differ in the way in which they support family care. France supports mothers in their care obligations through a scheme of various benefits, while Belgium puts the emphasis on job rotation and flexible labor-market organization.

Family policies in the Netherlands and the UK follow a similar principle giving priority to labor-market participation and market-provided care. Both countries seek to promote diversity and choice through encouraging market dynamics (Mahon 2002, 354).

In the German-speaking countries (Austria and Germany) family policies focus on mothers and on facilitating their retreating from the labor market. Public policies give priority to private care over public care. Policy regulations that are directed towards combining employment and care are underdeveloped and incoherent. Family benefits are generous, but benefits tied to care are low and insufficient to maintain a livelihood. Directly or indirectly, family policies in both countries are formed by the notion that caring mothers are supported by a male breadwinner.

If we compare these patterns of family policies to the patterns of fertility levels in Europe the answer to our initial question seems to suggest itself. Countries which regard their family policies as part of labor-market policies, of care policies, and of gender policies, seem to have retained fertility above lowest-low levels. They use strategies directed at changing the labor market so that both women and men are able to maintain their employment and income, even if they have (small) children to care for. It calls for a vast expansion of public provisions of childcare as a pre-requisite of parental employment. And it calls for policies that are directed towards changing the 
gender contract regarding the division of work and care in the family and in society. The goals of the EU to increase women's employment and public childcare are a first step to put the debate about women's care work, women's employment, family policies and fertility development in Europe on a new basis. 


\section{Endnotes}

${ }^{1}$ Council Directive 96/34/EC of 3 June 1996 on the framework agreement on parental leave concluded by UNICE, CEEP and ETUC (OJL 145, June 19, 1996, 4-9).

${ }^{2}$ Data for 2000 (Council of Europe 2001).

${ }^{3}$ The countries which did not have continual democratic regimes were Spain (until 1975), Portugal (until 1974) Greece (1967-1974), and the former state-socialist countries.

${ }^{4}$ Figure 5 displays the variance of the TFR among countries belonging to a particular region and between the regions. The regions contain the following countries:

North: Denmark, Norway, Sweden, Finland

Central - G[erman]: Germany (without Eastern Germany), Austria, Switzerland

Central - F, NL, UK: France, Belgium, the Netherlands, United Kingdom

South: Italy, Spain, Portugal, Greece

East: Poland, Hungary, Czech Republic, Slovakia, Slovenia, Bulgaria, Romania.

The variances were computed from the TFR of the countries belonging to a particular region (e.g.: Denmark, Norway, Sweden, Finland for the group "North") over the individual years for 5-resp. 6-year groups. We also calculated the variances including Eastern Germany among the Eastern European countries (not displayed here). Due to the dramatic decline of the TFR in Eastern Germany in the early 1990s, the intraregional variance increases for the years 1990-1995, but the general tendency towards a greater homogeneity within regions and a constant or sightly growing interregional variance is not affected by this increase.

${ }^{5}$ Because the TFR is sensitive to changes in the timing of births, demographers consider completed cohort fertility rates a better measure of fertility. Politically, however, the discourse about fertility decline and the potential impacts of family policies on fertility centers on the TFR, or even on the number of births.

${ }^{6}$ Campaigns or slogans launched recently in Austria and Germany to promote births had to be withdrawn because of adverse public reactions.

${ }^{7}$ For an example in demography, see Hoem, Prskawetz, and Neyer (2001); for a more general discussion with reference to economic and labor-market policies, see Hemerijck and Schludi (2000).

${ }^{8}$ Family-policy measures directed at partnership are closely connected to the regulation of marriage through civil law and the recognition of spouses in welfare-state and taxation systems. During the 1950 and 1960s marriage-based policies constituted a major component of family policies in Europe. Since the 1970s there has been a trend towards loosening the bond between marriage, taxation, and welfarestate schemes. The Scandinavian countries have moved furthest in this decoupling process and have largely individualized their taxation and welfare-state systems. The continental European countries still further marriage widely as opposed to cohabitation, for example, through granting spouses (but not all cohabitants) access to health care at no or only small costs, through providing for widow(er)'s pensions, or through allowing direct of indirect tax deductions (OECD 2001, 142).

${ }^{9}$ The reason for this is twofold: First, benefits granted through tax regulations are often only available to those mothers and/or fathers who have a high enough taxable income to make use of the deductions. Secondly, taxation systems may also grant higher deductions of other expenses (e.g. housing) if there are children in the household. It is difficult to assess to which extent such deductions affect the various types of households over time (for an assessment of tax benefits for children on "representative" types of households, see: Bradshaw and Finch 2002).

${ }^{10}$ Esping-Andersen tends to view the southern welfare states as part of the continental welfare-state regime, although he admits that the southern welfare states are an ambiguous case (Esping-Andersen 1999, 66).

${ }^{11}$ Gornick, Meyers, and Ross $(1997,53)$ use 18 family-policy and school indicators for their study: maternity leave, wage replacement rate, coverage, job protection, parental leave, paternity benefit, child-care expenditure, tax relief for child care, guaranteed childcare coverage (for children aged 0-2), 
guaranteed child care coverage (for children aged 4-5), percent children (aged 0-2) in publicly funded child care, percent children (aged 3-school-age) in publicly funded child care, percent children (aged 5) in preprimary care or school, percent children in publicly funded after-school care, starting age of compulsory school, school-day, school-year, continuous school day. For those countries for which data were available, these supports for maternal employment were also compared to the cash transfers (child benefits and means-tested assistance) paid directly to parents.

${ }^{12}$ Anttonen and Sipilä look at social care services for children as well as for the elderly. We report their findings regarding the provision of social care services for children.

13 Note that this description of the differences in policy discourses highlights only the major distinctions between European regions. Among the countries belonging to different regions and within the countries the discourses were very diverse. For an example of the differences between Norway, Sweden, and Denmark see Sainsbury (2001); for differences among Germany, Austria, and Switzerland see Neyer (1997).

${ }^{14}$ ILO (International Labour Organization) Maternity Protection Convention 1919 (No. 3), Revised 1952 (No. 103), Recommendations 1952 (No. 195); Revised 2000 (No. 183), Recommendations 2000 (No. 191). European Council Directive 92/85/EEC on the protection of pregnant workers and workers who have recently given birth or are breast-feeding.

${ }^{15}$ Council Directive 96/34/EC of 3 June 1996 on the framework agreement on parental leave concluded by UNICE, CEEP and ETUC (OJ L 145, June 1996). The directive required the incorporation of its regulation into national law by 3 June 1998 (resp. 3 June 1999).

${ }^{16}$ Except for the UK, all these countries had some kind of leave option, though it was not parental leave in a narrow sense. Since 1985, Belgium has offered the option of a (partially paid) career break or reduced working hours ranging from 3 to 12 months, with the possibility of extension up to 5 years. This career break has been open to all workers with employment of at least three-quarters time (Deven and Nuelant, 1999, 143). Parental leave had long been established in the public sector, but not in the private sector. Luxembourg had an option of a paid career break since 1988, but no guarantee of returning to the same or an equivalent workplace. Ireland and the UK had to introduce completely new legislation (Falkner et al. 2002).

${ }^{17}$ The home-care-allowance scheme started at the beginning of the 1970s and became a permanent part of the parental-leave and childcare system in 1985. In 1990 it was extended to all parents with children under age three (Simonen and Kovalainen 1998; Ilmakunnas 1997)

${ }^{18}$ The period may be extended to 52 weeks if the employer agrees. The extension is unpaid. The childcare leave was introduced in 1992 to reduce unemployment. Initially, the parent on childcare leave had to be replaced by an unemployed person for the duration of the leave (Leira 2002).

${ }^{19}$ The reason for this inequality is that Portugal implemented the EU-directive as a new law, without changing the existing regulations (Falkner et al. 2002).

${ }^{20}$ Norway, which is not a member of the EU and therefore did not need to implement the EC Directive, introduced an independent right to parental leave for fathers in 2000 (NOSOSCO 2002).

${ }^{21}$ The rates of father's uptake of parental leave still lie at below 1\% in Austria, $2 \%$ in Germany, 3\% in Denmark, 9\% in the Netherlands, and between 46 and 69\% in Sweden, Norway, and Finland (Bruning and Platenga 1999; Leira 2002). Even high take-up rates do not mean that parental leave is shared equally between mothers and fathers. During the 1990s, Swedish fathers took about $10 \%$ of the available benefit days, and they were between 27 and 36 days on parental leave (Sundström and Duvander 2002, 437).

${ }^{22}$ The Netherlands introduced parental leave in 1990, but it was only available on a part-time basis. Despite the fact that the Netherlands implemented a parental-leave option with a longer duration than required in the EC-Directive, the labor-market policy has been to promote part-time work of both women and men. The Netherlands have now one of the highest shares of part-time workers in Europe.

${ }^{23}$ Britain could not keep up its early net of childcare. In fact, the attendance of day nursery and nursery schools in Britain declined considerably during the early $20^{\text {th }}$ century (Bahle 1995,102$)$. Kamerman 
$(2000,4)$ attributes this to the institutional and political failures to raise the quality of day-care nurseries and to integrate them into the pre-school system (Kamerman 2000,4).

${ }^{24}$ According to Hemerijck $(2002,198 \mathrm{f}$.) the Netherlands now have the highest rate of firm-provided and subsidized private daycare.

${ }^{25}$ In the case of Austria the maternity-leave legislation of 1957 even eliminated a regulation by which employers were to provide childcare or contribute to the financing of public childcare institutions (Neyer 1998).

${ }^{26}$ In Denmark, the expansion of public childcare started already in the late 1950s (Sipilä et al. 1997, 37), and was further enhanced by legislation in the middle of the 1960s (Borchorst and Siim 1987)

${ }^{27}$ Available statistics are not readily comparable. This is partly due to the way in which coverage is calculated. As Korpi $(2000,145)$ noted it is not always clear whether the available data represent percentage of children attending, children with the right to claim a place, or available places. Furthermore, children who use more individualized forms of childcare (e.g.: child-minders) may not always be included in the data. For problems regarding the collection and comparability of childcare statistics in Europe, see: European Commission 2002.

${ }^{28}$ In the Netherlands there are currently two different systems in use. Child benefit for children born before 1994 is paid according to age and number of children; for children born since 1995 the amount of family benefit depends solely on the age of the child.

${ }^{29}$ Belgium has currently also several systems, depending on the year of birth of the child. 


\section{Appendix: Demographic research of policy effects on fertility}

During the past decades demographic research has largely focused on economic and cultural factors as the driving forces behind changes in fertility patterns and fertility behavior. Despite the fact that concurrent developments of fertility and family policies in European countries have underpinned assumptions that family policies and fertility outcomes are mutually intertwined (Gauthier 1996a; Chesnais 1996), demographic inquiries into the effects of public policies on fertility developments in European countries are still rather scarce. Research in this area may be largely divided into two groups. The first one comprises studies that investigate the effects of selected policies on childbearing behavior. (Hoem 1990, 1993; Blanchet and Ekert-Jaffé 1994; Ekert 1986; Ekert et al. 2002; Hoem and Hoem 1996; Gauthier and Hatzius 1997; Oláh 2001; Rønsen 1999; Hoem et al 2001; Gauthier and Hatzius 1997; Wennemo 1994; Kravdal 1996; Kreyenfeld 2002; Hank 2002; Del Boca 2002). The second group covers research that deals with the effects of public policies on mother's laborforce participation after childbirth (Sundström and Stafford 1992; Ellingsaeter and Rønsen 1996; Rønsen and Sundström 1996; Rønsen 1999; Ondrich et al 1996, 2003; McRae 1993; Gustafsson et al. 1996; Saurel-Cubizolles et al. 1999). The majority of both types of studies focuses on rather short-term implications of policies and concentrates on policies directly related to childbearing or child rearing, such as maternity benefits, parental-leave benefits, family benefits or child-care provisions.

Studies that deal with fertility impacts of public policies usually investigate the effects of policies in a particular country. Only a few studies take a comparative approach. Gauthier and Hatzius (1997) analyze the effects of family-cash benefits and maternity benefits in several countries. They find that family-cash benefits in form of family allowances are positively related to fertility (though the effects are of limited magnitude), while maternity benefits (duration and amount of benefit) were not significantly related to fertility. Wennemo (1994), investigating family benefits and tax reductions in 18 OECD-countries states that "even if the intention of family support programs has been to increase birth rates, this goal does not seem to have been achieved" (Wennemo 1994, 213). 
Among the single-country studies the Swedish parental-leave system has received the most extensive research coverage. Hoem (1990, 1993), Hoem and Hoem (1996), and Andersson (1999; 2002) show that the introduction of a "speed premium" in the Swedish parental-leave system during the 1980s had a positive influence on the timing of childbearing. The "speed premium", which retains the benefit level for mothers/parents who have their second or subsequent child within a restricted period of time after a previous birth, led to changes in the spacing of births and may have contributed to the rise in Sweden's total fertility during the 1980s. Confirming results about Sweden and the effects of its parental-leave system on fertility have been found by Sundström and Stafford (1992). Hoem, Prskawetz and Neyer (1999; 2001), who investigate transitions to third births in Austria, found similar effects on the spacing of childbirths, brought about by a change of parental-leave policies that also privileged mothers who had their second or subsequent child within a given period after the previous one. The policy changes had a possible diminishing effect on the decline of the third-birth fertility rate in Austria, but did not have a noticeable impact on the total fertility level. Ekert-Jaffé et al. (2002) comparing France and Britain see a clear effect of French family policy on the progression to third births and the timing of birth in France (Ekert-Jaffé et al. 2002, 492, 494).

Hypotheses that more gender-equal relationships may have a positive effect on fertility (McDonald 2000a, 2000b; Chesnais 1996) are supported by research on fathers' uptake of parental leave in Sweden. Oláh (2001) shows that couples in which the man fails to take parental leave with the first child have a lower propensity to have a second child than couples in which the father did take (some) parental leave. Duvander and Andersson (2003) conclude from their analysis of Swedish data that a moderate length of the father's parental leave has a positive effect on the transition to second and to third birth, while long or short leaves do not. They also find that a long duration of the mother's parental leave increases the propensity to have a third child.

Studies of the interrelation between childcare provisions and fertility have rendered only small effects. Kravdal (1996) finds for Norway that the availability of public childcare is positively related to the probability of having a third child, but he observes no or even declining effects of childcare coverage on the probability of having a first or second child. He concludes that an increase in the provision of public 
and private childcare would have "little stimulating effect on fertility" (Kravdal 1996). Similar results were noted by Kreyenfeld (2002) and Hank (2002) with regard to West Germany, a country with very low coverage of public childcare. Kreyenfeld (2002) and Hank (2002) find no effect of the availability of public childcare on first and second birth intensities in West Germany. Yet, comparing the availability of public and private childcare provisions in East and West Germany, Hank, Kreyenfeld and Spiess (2003) show that in Eastern Germany the availability of public childcare has a positive influence on the transition to first birth, while in West Germany only the availability of informal care arrangements renders statistically significant results.

Although the differences in results encountered in the studies we reviewed may be partly attributed to differences in the aims of research, the research design, the data, the methods used, as well as the country and the period covered (Gauthier 1996b, 320-325), the overall results draw an ambiguous picture of the potential impacts of family policies on fertility (Hantrais 1997, 341). Some of the policies studied show varying and sometimes even contradictory results (Gauthier 1996b, 314319; Gauthier 2001, 13; Gauthier 2002). Family allowances, the level or the duration of maternity benefit, as well as the availability or the costs of childcare seem to have some effects on childbearing behavior, but the measurable effects are small and not always significant. The results are more encouraging as far as parental leave is concerned. Although the studies have concentrated on the effects of changes in parental-leave provisions, they show that the length of parental leave as well as the benefit structure may have an impact on the timing of birth and on parity progression. The results further indicate that the length of the parental-leave period taken by the mother and/or taken by the father influences the transition to a subsequent birth. Despite the fact that parental-leave policies seem to affect the timing of births and the transition to subsequent births, we lack evidence that these effects on childbearing behavior may have a long-term impact on the level of fertility.

Studies that concentrate on the impact of parental-leave policies on subsequent childbearing capture a specific group of women, namely those who had been employed prior to the birth of the child that led to the uptake of parental leave. Parental-leave policies may thus also have an impact on women's re-entry into the labor market, which in turn may affect subsequent childbearing. Demographic 
research that looks at the relationship between parental leave and women's employment also reveals differing results. Most studies pertaining to the Nordic countries exhibit a positive effect of parental leave on mothers' resumption of paid work after childbearing (Ellingsaeter and Rønsen 1996; Rønsen and Sundström 1996, 1997), but varying effects with respect to the duration of parental leave (Rønsen and Sundström 1996, 1997; Rønsen 1999). In Norway, Finland, and Sweden alike, women with entitlement to paid leave have much higher (re-)employment risks. However, women who use parental leave show such higher re-entry intensities only at the immediate end of the parental-leave entitlement. The exception is Sweden, where more flexible regulations regarding leaves and employment allow women to block their parental leave. As expected mothers with higher education have higher return rates than mothers with lower education do. Yet, in Norway, women with higher education opt more often for part-time work after parental leave, while in Sweden more highly educated women return earlier and to full-time work (Rønsen and Sundström 1997). The studies also show that when statutory leaves are prolonged - as was the case in Finland during the late 1980s - mothers tend to stay home longer. In fact, in Sweden re-entry intensities varied over the periods of with different parental leave legislations (Rønsen and Sundström 1997). Such longer breaks reduce the propensity of re-entry, especially for women with low earning potentials (Rønsen and Sundström 1999; Ilmakunnas (1997).

Research on women's return to paid work after childbirth in other European countries reveal similar non-homogenous effects of parental-leave policies as well as of maternity-leave policies. Ondrich, Spiess, and Yang (1996) analyze the effect of the German "Bundeserziehungsgeld", a form of benefit ranging between childminding allowance and parental-leave benefit and they maintain that after the leave period (West-)German mothers with the strongest attachment to the labor force return to their jobs, while part-time workers are less likely to return to work after parental leave. With the extension of parental leave, however, the pattern of return seems to become more variable. Women with more education and greater labor-force experience seem to take advantage of the full length of leave more often than women with less education and less labor-force experience (Ondrich, Spiess, Yang, and Wagner 2003). Surprisingly, and contrary to the findings for Sweden and Norway 
(Rønsen and Sundström 1997) one-child mothers in (West-)Germany show lower propensities to return to work after parental leave than mothers with more than one child. Neyer et al (1998) also find that in Austria women's return to work after parental leave is influenced by their employment career, employment status, and income level prior to the birth of their child. They further note that the extension of the Austrian parental leave from one to two years had a depressing effect on the reentry rates of one-child mothers at the end of the parental-leave period. But this was partly caused by legislation that made it necessary for women (with only one year of parental leave), who had another child shortly after the first one, to return to the labor market in order to uphold their entitlements to parental-leave benefits.

Comparative studies confirm the potential impact of childbearing, maternity leave, and parental-leave policies on mothers' employment. Gustafsson et al. (1996) attribute different return rates in Germany, Great Britain, and Sweden to the different social policies for mothers in these countries, as do Saurel-Cubizolles et al. (1999) with respect to France, Italy, and Spain. Ruhm and Teague (1997) and Ruhm (1998) state that short or moderate periods of parental leave are associated with increases in women's employment, while longer leaves are negatively related to labor-market outcomes (employment and relative wages).

In the light of demographer's notions about the relationship between fertility and female employment these findings make it even more difficult to state conclusive results as to what effects family policies have on fertility. Parental-leave policies seem to encourage re-entry into the labor market after childbearing. Yet, as with the impact of parental leave on subsequent childbearing, the direction of the effects seems to depend on the length of parental leave. Moreover, re-entry patterns vary considerably across countries, in particular with regard to women of a similar socio-economic background. This supports views that the differences in outcomes are connected to cross-national variation in the nature of family-policy provisions and in their objectives. 


\section{References:}

Ahn, Namkee and Pedro Mira (2002): A note on the changing employment relationship between fertility and female employment rates in developed countries. In: Journal of Population Economics 15/4, 667-682.

Andersson, Gunnar (2002): Fertility development in Norway and Sweden since the early 1960s. In: Demographic Research 6/4, 67-86: http://www.demographic-research.org/Volumes/Vol6/4/

Andersson, Gunnar (2000): The impact of labor-force participation on childbearing behavior: Procyclical fertility in Sweden during the 1980s and the 1990s. In: European Journal of Population 16, 293-333.

Andersson, Gunnar (1999): Childbearing trends in Sweden 1961-1997. In: European Journal of Population 15, 1-24.

Anttonen, Anneli and Jorma Sipilä (1996): European social care services: Is it possible to identify models?. In: Journal of European Social Policy 6/2, 87-100.

Anttonen, Anneli (2001): The politics of social care in Finland: Child and elder care in transition. In: Daly, Mary (ed.): Care work. The quest for security. International Labour Office: Geneva, 143-158.

Bahle, Thomas (1995): Familienpolitik in Westeuropa. Ursprünge und Wandel im internationalen Vergleich. Campus: Frankfurt a.M.

Bergqvist, Christina et al (1999): Equal democracies? Gender and politics in the Nordic countries. Scandinavian University Press: Oslo.

Bergqvist, Christina, and Anita Nyberg (2002): Welfare state restructuring and child care in Sweden. In: Michel, Sonya and Rianne Mahon (eds.): Child care policy at the crossroads. Gender and welfare state restructuring. Routledge: New York - London, 287-308.

Billari, Francesco and Chris Wilson (2001): Convergence towards Ddversity? Cohort dynamics in the transition to adulthood in contemporary Western Europe. MPIDR-working papers WP-2001-39: http://www.demogr.mpg.de/Papers/Working/WP-2001-039.pdf.

Blanchet, Didier and Olivia Ekert-Jaffé (1994): The demographic impact of family benefits: evidence from a micro-model and from macro-data. In: Ermisch, John and Naohiro Ogawa (eds.): The family, the market and the state in ageing societies. Clarendon Press, Oxford, 79-104

Bock, Gisela and Pat Thane (eds.) (1991): Maternity and gender policies. Women and the rise of the European welfare states 1880s - 1950s. Routledge: London.

Bollé, Patrick (2001): Parental Leave. In: Loutfi, Martha Fetherolf (ed.): Women, gender, and work. What is equality and how do we get there? International Labour Office: Geneva, 347-367 (originally published in: International Labour Review 136, 1997).

Borchorst, Anette (2002): Danish child care policy: Continuity rather than radical change. In: Michel, Sonya and Rianne Mahon (eds.): Child care policy at the crossroads. Gender and welfare state Restructuring. Routledge: London, 267-286.

Borchorst, Anette and Birte Siim (1987): Women and the advanced welfare state - a new kind of patriarchal power? In: Sassoon, Anne Showstack (ed.): Women and the state. Hutchinson: London, 128-157.

Bourdieu, Pierre (1996): On the family as a realized category. In: Theory, Culture \& Society 13/3, 1926.

Bradshaw, Jonathan et al. (1993): A comparative study of child support in fifteen countries. In: Journal of European Social Policy 3/4, 255-271. 
Bradshaw, Jonathan and Naomi Finch (2002): A comparison of child benefit packages in 22 countries - a summary of the child benefit package of each country. Research Report No 174. Department for Work and Pensions. London: http://www.dwp.gov.uk/asd/asd5/rrep174.html

Bruning, Gwennaële and Janneke Platenga (1999): Parental Leave and equal opportunities: experiences in eight European countries. In: Journal of European Social Policy 9/3, 195-209.

Bussemaker, Jet (1998): Rationales of care in contemporary welfare states: The case of childcare in the Netherlands. In: Social Politics 5/1, 70-96.

Bussemaker, Jet and Kees van Kersbergen (1999): Contemporary social-capitalist welfare states and gender inequality. In: Sainsbury, Diane (ed.) (1999): Gender and welfare state regimes. Oxford University Press: Oxford, 15-46.

Chesnais, Jean-Claude (1996): Fertility, family, and social policy in contemporary Western Europe. In: Population and Development Review 22/4, 729-739.

Council of Europe (2001): Recent demographic developments in Europe 2000. Council of Europe: Strasbourg.

Cova, Anne (1991): French feminism and maternity: theories and policies, 1890-1918. In: Bock, Gisela and Pat Thane (eds.): Maternity and gender policies. Women and the rise of the European welfare states 1880s - 1950s. Routledge: London, 119-137.

Daly, Mary and Jane Lewis (2000): The concept of social care and the analysis of contemporary welfare states. In: British Journal of Sociology 50/2, 281-298.

Daly, Mary (2000): A fine balance. Women's labor market participation in international comparison. In: Scharpf, Fritz and Vivien A. Schmidt (eds.) Welfare and work in the open economy. Vol. II. Diverse responses to common challenges, Oxford University Press: Oxford, 467-510.

Daly, Mary and Jane Lewis (1998): Introduction: Conceptualising social care in the context of welfare state restructuring. In: Lewis, Jane ed. Gender, social care and welfare state restructuring in Europe, Aldershot: Ashgate.

Daly, Mary (1997): Welfare states under pressure: Cash benefits in European welfare states over the last ten years. In: Journal of European Social Policy 7/2, 129-146.

Del Boca, Daniela (2002): The effect of child care and part time opportunities on participation and fertility decisions in Italy. Journal of Population Economics 15 (3).

Della Sala, Vincent (2002): "Modernization" and welfare-state restructuring in Italy: The impact on child care. In: Michel, Sonya and Rianne Mahon (eds.): Child care policy at the Crossroads. Gender and welfare state restructuring. Routledge: New York - London, 171-190.

Denk, G., and H. Schattovits (1995): Teilzeitbetreuung von Kindern in Österreich. Eine Bestandsaufnahme zur Orientierung über Formen, Kosten und Finanzierung. Institut für Familienforschung: Wien.

Deven, Fred and Tanja Nuelant (1999): Parental leave and career breaks in Belgium. In: Moss, Peter and Fred Deven (eds.): Parental leave: Progress or pitfall? Research and policy issues in Europe. NIDI/CBGS Publications 35: Brussels, 141-154.

Duvander, Ann-Zofie, and Gunnar Andersson (2003): Gender equality and fertility in Sweden: An investigation of the impact of the father's use of parental leave on continued childbearing (forthcoming). 
Eichinger, Julia (1997): Frauenarbeitsrecht im Überblick. Unter besonderer Berücksichtigung des Arbeitsrechtlichen Begleitgesetzes zur Pensionsreform. In: Aichhorn, U., ed. Frau \& Recht. Springer: Wien, 39-82.

Ekert, Olivia (1986): Effects et limites des aides financière aux familles: une expérience et un modèle. In: Population 41/2, 327-348.

Ekert-Jaffé, Olivia et al. (2002): Fertility, timing of births and socio-economic status in France and Britain. In: Population (English) 7/3, 475-508.

Ellingsaeter, Anne Lise and Margit Rønsen (1996): The Dual Strategy: Motherhood and the Work Contract in Skandinavia”. In: European Journal of Population 12/3, 239-260

Engelhardt, Henriette, Tomas Kögel, and Alexia Prskawetz (2001): Fertility and female employment reconsidered: A macro-level time series analysis. MPIDR Working Paper WP-2001-021, http://www.demogr.mpg.de/Papers/Working/wp-2001-021.pdf

Esping-Andersen, Gøsta (1990): The three worlds of welfare capitalism. Polity Press: Cambridge.

Esping-Andersen, Gøsta (1999): Social Foundations of Postindustrial Economies. Oxford University Press: Oxford.

Esping-Andersen, Gøsta (2002a): A new gender contract. In: Esping-Andersen, Gøsta with Duncan Gallie, Anton Hemerijck, and John Myles: Why we need a new welfare state. Oxford University Press: Oxford, 68-95.

Esping-Andersen, Gøsta (2002b): A child-centered social investment strategy. In: Esping-Andersen, Gøsta with Duncan Gallie, Anton Hemerijck, and John Myles: Why we need a new welfare state. Oxford University Press: Oxford, 26-67.

Esping-Andersen, Gøsta with Duncan Gallie, Anton Hemerijck, and John Myles (2002): Why we need a new welfare state. Oxford University Press: Oxford.

European Commission (2002): Feasibility study on the availability of comparable child care statistics in the European Union. EUROSTAT working papers.

European Council (2002): Presidency Conclusions. Barcelona European Council 15 and 16 March 2002. http://europa.eu.int/council/off/conclu/.

Falkner, Gerda et al. (2002): Transforming social policy in Europe? The EC's parental leave directive and misfit in the 15 member states. MPIfG Working Paper 02/11, October 2002: http://www.mpi-fgkoeln.mpg.de/pu/workpap/wp02-11/wp02-11.html

Faßmann, Heinz and Elisabeth Aufhauser, and Rainer Münz (1988): Kindergärten in Österreich. Angebot-Nachfrage-Defizite. Bundesministerium für Umwelt, Jugend und Familie: Wien.

Ferrera, Maurizio (1996): The Southern welfare state in social Europe". In: Journal of European Social Policy 6/1, 17-37.

Flora, Peter and Arnold J. Heidenheimer (eds.) (1995): The development of welfare states in Europe and America. Transaction Publishers: New Brunswick/London.

Fraser, Nancy (2000): Rethinking recognition. In: New Left Review 3, 107-120.

Fraser, Nancy (1997): After the family wage: Gender equity and the welfare state. In: Fraser, Nancy: Justice Interruptus: Critical reflections on the "Postsocialist" Condition. XXXX: New York.

Fraser, Nancy (1989): Unruly practices: Power, discourse and gender in contemporary social theory. Polity Press: Cambridge-Oxford. 
Gary, Gisela (1995): Geschichte der Kindergärtnerin von 1779 bis 1918. Edition Praesens: Wien.

Gauthier, Anne H.(1996a): The state and the family. A comparative analysis of family policies in industrialized countries. Clarendon Press: Oxford.

Gauthier, Anne H. (1996b): The measured and unmeasured effects of welfare benefits on families: Implications for Europe's demographic trends. In: Coleman, David (ed.): Europe's Population in the 1990s. Oxford University Press: Oxford, 297-331.

Gauthier, Anne H. (2001): The impact of public policies on families and demographic behaviour. Paper presented at the ESF/EURESCO conference 'The second demographic transition in Europe'. Bad Herrenalb, Germany, June 2001.

Gauthier, Anne H. (2002): Family policies in industrialized countries: Is there a convergence? In: Population 57 (3), 447-474.

Gauthier, Anne H. and Anita Bortnik (2001). Comparative Maternity, Parental, and Childcare Database, Version 2. University of Calgary:

http://www.soci.ucalgary.ca/fypp/family_policy_databases.htm

Gauthier, Anne H. and Jan Hatzius (1997): Family benefits and fertility. An econometric analysis. In: Population Studies 51/3, 295-306.

Gornick, Janet C., Marcia K. Meyers, and Katherin E. Ross (1997): Supporting the employment of mothers: Policy variation across fourteen welfare states. In: Journal of European Social Policy 7/1, 4570 .

Gustafsson, Siv et al. (1996): Women's labor force transitions in connection with childbirth: A panel data comparison between Germany, Sweden and Great Britain. In: Journal of Population Economics 9/3, 223-246.

Hammer, Gerhard (1997): 'Kinderbetreuung. Ausgewählte Hauptergebnisse des Mikrozensus September 1995'. Statistische Nachrichten 3, 168-75.

Hank, Karsten (2002): Regional social contexts and individual fertility decisions: A multilevel analysis of first and second births in Western Germany. European Journal of Population 18 (4).

Hank, Karsten, Michaela Kreyenfeld, and C. Katharina Spieß (2003): Kinderbetreuung und Fertilität in Deutschland. MPIDR Working Papers WP-2003-002: http://www.demogr.mpg.de/papers/working/wp2003-002.pdf

Hantrais, Linda (1994): Comparing family policies in Britain, France and Germany. In: Journal of social policy 23/2, 135-160.

Hantrais, Linda (1997): Exploring relationships between social policy and changing family forms within the European Union. In: European Journal of Population 13, 339-379.

Hantrais, Linda and Marie-Thérèse Letablier (1996): Families and family policies in Europe. Longman: London-New York.

Heinen, Jacqueline and Heini Martiskainen de Koenigswarter (2001): Framing citizenship in France and Finland in the 1990s: Restructuring Motherhood, work, and care. In: Social politics 8/2, 170-181.

Hemerijck, Anton C. (2002): The self-transformation of the European social model(s). In: EspingAndersen, Gøsta with Duncan Gallie, Anton C. Hemerijck, and John Myles: Why we need a new welfare state. Oxford University Press: Oxford, 173-213.

Hemerijck, Anton C. and Martin Schludi (2000): Sequences of policy failures and effective policy responses. In: Scharpf, Fritz W. and Vivien A. Schmidt (eds.): Welfare and work in the open economy. Volume I: From vulnerability to competitiveness. Oxford University Press: Oxford, 125-228. 
Hermeijk, Anton C., Brigitte Unger, and Jelle Visser (2000): How small countries negotiate change. Twenty-five years of policy adjustment in Austria, the Netherlands, and Belgium. In: In: Scharpf, Fritz W. and Vivien A. Schmidt (eds.): Welfare and work in the open economy. Volume II: Diverse responses to common challenges. Oxford University Press: Oxford, 175-263.

Hernes, Helga Maria (1987): Welfare state and women's power. Norwegian University Press: Oslo.

Hobson, Barbara and Marika Lindholm (1997): Collective identities, women's power resources, and the making of welfare states. In: Theory and Society 26, 457-508.

Hobson, Barbara (1990): No Exit, No Voice: Women's economic dependency and the welfare state. In: Acta Sociologica 33/3, 235-250.

Hoem, Jan M. (1990): Social policy and recent fertility change in Sweden. In: Population and Development Review 16, 735-748.

Hoem, Jan M. (1993): Public Policy as the fuel of fertility: effects of a policy reform on the pace of childbearing in Sweden in the 1980s. In: Acta Sociologica 36, 19-31.

Hoem, Britta and Jan M. Hoem (1996): Sweden's family policies and roller-coaster fertility. In: Journal of Population Problems (Tokyo) 52/3-4, 1-22.

Hoem, Jan M., Alexia Prskawetz, and Gerda Neyer (2001): Autonomy or conservative adjustment? The effect of public policies and educational attainment on third births in Austria, 1975-96. In: Population Studies 55, 249-261. For a longer version see: http://www.demogr.mpg.de/Papers/Working/wp-2001016.pdf

Ilmakunnas, Seija (1997): Public policies and childcare choice. In: Persson, Inga and Christina Jonung (eds.): Economics of the family and family policies. Routledge: London, 179-193.

Kamerman, Sheila B. and Alfred J. Kahn (1978): Family policy - Government and families in fourteen countries. Columbia Press: New York.

Kamerman, Sheila B. and Alfred J. Kahn (1991): Child care, parental leave, and the under 3s. Policy innovation in Europe. Auburn House: New York.

Kamerman, Sheila B. (2000): Early childhood education and care (ECEC): An overview of developments in the OECD countries. Research paper for the consultative meeting on international developments in early childhood education and care (ECEC), Columbia University, May 11 and 12, 2000: http://www.childpolicy.org/publications.htm.

Klaus, Alisa (1993): Depopulation and race suicide: Maternalism and pronatalist ideologies in France and the United States. In: Koven, Seth and Sonya Michel (eds.): Mothers of a new world: Maternalist politics and the origins of welfare states. Routledge: London, 188-212.

Knijn, Trudie (1998): Social care in the Netherlands. In: Lewis, Jane (ed.): Gender, social care and welfare state restructuring in Europe. Ashgate: Aldershot, 85-109.

Knijn, Trudie and Monique Kremer (1997): Gender and the caring dimension of welfare states: towards inclusive citizenship. In: Social Politics 4/3, 328-361.

Korpi, Walter (2000): Faces of inequality: Gender, class, and patterns of inequalities in different types of welfare states. In: Social Politics 7/2, 127-189.

Koven, Seth and Sonya Michel (1993): Mothers of the new world. Maternalist politics and the origin of welfare states. Routledge: London.

Kögel, Tomas (2002): Did the association between fertility and female employment within OECD countries really change its sign? MPIDR Working Paper WP-2001-34 (Revised July 2002). 
Kravdal, Øystein (1996): How the local supply of day-care centers influences fertility in Norway: A parity-specific approach. Population Research and Policy Review 15, 201-218.

Kremer, Monique (2002): The illusion of free choice: Ideals of care and child care policy in Flemish and Dutch welfare states. In: Michel, Sonya and Rianne Mahon (eds.): Child care policy at the crossroads. Gender and welfare state restructuring. Routledge: New York-London, 113-142.

Kreyenfeld, Michaela (2002): A multilevel analysis of child care and the transition to motherhood in Western Germany. DIW-Berlin, Discussion Paper 290, July.

Land, Hilary and Jane Lewis (1998): Gender, care and the changing role of the state in the UK. In: Lewis, Jane (ed.): Gender, social care and welfare state restructuring in Europe. Ashgate: Aldershot, 51-84.

Langan, Maryand Ilona Ostner (1991): Geschlechterpolitik im Wohlfahrtsstaat: Aspekte im internationalen Vergleich. In: Kritische Justiz, 302-317.

Leibfried, Stefan (1992): Towards a European welfare state: On integrating poverty regimes into the European community. In: Zsusa Ferge and Jan E. Kolberg (eds.): Social policy in a changing Europe. Campus: Frankfurt, 245-280.

Leira, Arnlaug (2002): Working parents and the welfare state. Family change and policy reform in Scandinavia. Cambridge University Press: Cambridge.

Lesthaeghe, Ron and Guy Moors (2000): Recent trends in fertility and household formation in the industrialized world. In: Review of Population and Social Policy 9, 121-171.

Lewis, Jane (2001): Is marriage the answer to the problems of family change. In: The Political Quarterly publishing, 437-445.

Lewis, Jane (2001): Debates and issues regarding marriage and cohabitation in the British and American literature. In: International Journal of Law, Policy and the Family 15, 159 - 184.

Lewis, Jane (2001): The decline of the male breadwinner model: implications for work and care. In: Social Politics 8/2, 152-169.

Lewis, Jane et al. (1999): Sources of income for lone mother families: Policy changes in Britain and the Netherlands and the experiences of divorced women. In: Journal of Social Policy 28/4, 619-641.

Lewis, Jane (1998): 'Work', 'welfare', and lone mothers. In: The Political Quarterly 69/1, 4-13.

Lewis, Jane (ed.) (1997): Lone mothers in European welfare regimes. Shifting policy logics. Jessica Kingsley Publishers: London.

Lewis, Jane (1997): Gender and welfare regimes: Further thoughts. In: Social Politics 4/2, 160-177.

Lewis, Jane (1992): Gender and the development of welfare regimes. In: Journal of European Social Policy 3, 159-173.

Lewis, Jane and Gertrude Aström (1992): Equality, difference, and state welfare: Labour market and family policies in Sweden. In: Feminist Studies 18/1, 59-87.

Lister, Ruth (2000): Towards a citizens' welfare state - The 3+2 'R's of welfare reform. In: Theory, Culture \& Society 18/2-3, 91-111.

Lister, Ruth (1997): Dialectics of citizenship. In: Hypatia 12/4, 7-26.

Lister, Ruth (1997): Citizenship: Towards a feminist synthesis. In: Feminist Review 57, 28-48. 
Lister, Ruth (1995): Dilemmas in engendering citizenship. In: Economy and Society 24/1, 1-40.

Lister, Ruth (1990): Women, economic dependency and citizenship. In: Journal of Social Policy 19/4, 445-467.

Mahon, Rianne (2002): Child care: Toward what kind of "social Europe"? In: Social Politics 9/3, 343379 .

McRae, Susan (1993): Returning to work after childbirth: opportunities and inequalities. In: European Sociological Review 9/2, 125-138.

Mairhuber, I. (1998): 'Soziale Sicherung in Italien'. In: Tálos, E. ed. Soziale Sicherung im Wandel. Österreich und seine Nachbarn. Böhlau: Wien.

Martin, Claude, Antoine Math, and Evelyne Renaudat (1998): Caring for the very young and elderly people in France: Towards a commodification of social care? In: Lewis, Jane (ed.): Gender, social care and welfare state restructuring in Europe. Ashgate: Aldershot, 139-173.

McDonald, Peter (2000a): Gender equity in theories of fertility transition. In: Population and Development Review 26/3, 427-439

McDonald, Peter (2000b): Gender equity, social institutions and the future of fertility. In: Journal of Population Research 17/1, 1-16.

McDougall, Mary Lynn (1983): Protecting infants: The French campaign for maternity leaves, 1890s1913. In: French Historical Studies 13, 1, 79-105.

Meyers, Marcia K. and Janet C. Gornick (2000): Early childhood education and care (ECEC): Crossnational variation in service organization and financing. The Clearinghouse on international development of child, youth and family policy at Columbia University: http://www.childpolicy.org/publications.htm

Meyers, Marcia K., Janet C. Gornick, and Katherin E. Ross (1999): Public childcare, parental leave, and employment. In: Sainsbury, Diane (ed.): Gender and welfare state regimes. Oxford University Press: Oxford, 117-146.

Missoc (2001): Social protection in the member states in the EU member states and the European economic area: http://europa.eu.int/comm/employment_social/missoc/index_en.html

Moeller, Robert G. (1993): Protecting motherhood: women and the family in the politics of postwar West Germany. University of California Press: Berkeley.

Montanari, Ingalill (2000): From family wage to marriage subsidy and child benefits: Controversy and consensus in the development in family support. In: Journal of European Social Policy 10/4, 307-333.

Morgan, Kimberly (2002): Does anyone have a "libre choix"? Subversive liberalism and the politics of French child care policy. In: Michel, Sonya and Rianne Mahon (eds.): Child care policy at the crossroads. Gender and welfare state restructuring. Routledge: New York - London, 143-167.

Moss, Peter and Fred Deven (eds.) (1999): Parental leave: Progress or pitfall? Research and policy issues in Europe. NIDI/CBGS Publications 35: Brussels

Neyer, Gerda (ed. forthcoming): Family change and family policy in Austria. In: Bahle, Thomas and Peter Flora (eds.): Family change and family policies in Europe. Oxford University Press: Oxford.

Neyer, Gerda (1999): Gender and the fraternal Austrian welfare state: Parental leave policies as gendering policies. In: Boxer, M.J., Quataert, J.H., eds. Connecting spheres: European women in a globalizing world, 1500 to the Present. Oxford University Press: Oxford, 306-13.

Neyer, Gerda et al. (1998): Karenzurlaub. Forschungsbericht des Instituts für Demographie, Vienna. 
Neyer, Gerda (1997): Die Entwicklung des Mutterschutzes in Deutschland, Österreich und der Schweiz von 1877 bis 1945. In: Gerhard, U., ed. Frauen in der Geschichte des Rechts. Von der frühen Neuzeit bis zur Gegenwart. Verlag C.H. Beck: München, 744-58.

Neyer, Gerda (1995): Institutionelle Kinderbetreuung in Österreich. In: Bundesministerin für Frauenangelegenheiten/Bundeskanzleramt, ed. Bericht über die Situation der Frauen, Frauenbericht. Bundesministerin für Frauenangelegenheiten: Wien, 73-79.

Neyer, Gerda (ed.) (1990): Risiko und Sicherheit: Mutterschutzleistungen in Österreich. Wirkung von Karenzgeld und Sonder-Notstandshilfe auf die Arbeitsmarktsituation von Frauen. Forschungsberichte aus Arbeitsmarkt- und Sozialforschung 30. Bundesministerium für Arbeit und Soziales: Wien.

NOSOSCO (2002): Social protection in the Nordic countries 2000. Scope, expenditure and financing. Nordic Social-Statistical Committee no 18:02. Copenhagen: http://www.nom-nos.dk/nososco.htm

OECD (2001a): Employment outlook. Chapter 4: Balancing work and family life: Helping parents into paid employment. Paris.

OECD (2001b): Starting strong. Early childhood education and care. Paris.

OECD (1998): Labour force statistics 1977-1997. Paris.

Offen, Karen (1991): Body politics: women, work and the politics of motherhood in France, 19201950. In: Bock, Gisela, and Pat Thane (eds.): Maternity and gender policies. Women and the rise of the European welfare states 1880s - 1950s. Routledge: London, 138-159.

Oláh, Livia Sz. (2001): Gendering family dynamics: The case of Sweden and Hungary. Stockholm: Stockholm University Demographic Unit - Dissertation Series.

Ondrich, Jan, C. Katharina Spiess, Qing Yang, and Gert G. Wagner (2003): The liberalization of maternity leave policy and the return to work after childbirth in Germany. In: Review of Economics of the Household 1, 77-103.

Ondrich, Jan, C. Katharina Spiess, Qing Yang (1996): Barefoot and in a German kitchen: Federal parental leave and benefit policy and the return to work after childbirth in Germany. In: Population Economics 9, 247-266.

Orloff, Ann Shola (1993): Gender and the social rights of citizenship: The comparative analysis of gender relations and welfare states. In: American Sociological Review 58/3, 303-328.

Ostner, Ilona (1994): Back to the fifties: Gender and welfare in unified Germany. In: Social Politics $1 / 1,32-59$.

Ostner, Ilona (1998): The politics of care policies in Germany. In: Lewis, Jane (ed.): Gender, social care and welfare state restructuring in Europe. Ashgate: Aldershot, 111-137.

Pawlowsky V. (1997): Die Mütter der Wiener Findelkinder. Zur rechtlichen Situation ledig gebärender Frauen im 18. und 19. Jahrhundert. In: Gerhard, U., ed. Frauen in der Geschichte des Rechts: Von der Frühen Neuzeit bis zur Gegenwart. Beck: München, 367-81.

Pedersen, Susan (1993): Family, dependence, and the origins of the welfare state. Britain and France, 1914-1945. Cambridge University Press: Cambridge.

Pfau-Effinger, Birgit (1999): Change of family policies in the socio-cultural context of European societies. In: Comparative Social Research 18, 135-159.

Plantenga, Janneke and Johan Hansen (2001): Assessing equal opportunities in the European Union. In: Loutfi, Martha Fetherolf (ed.): Women, gender and work. What is equality and how do we get there? 
International Labour Office: Geneva, 273-304. (originally published in : International labour review 138/4, 1999).

Randall, Vicky (2002): Child care in Britain, or, how do you restructure nothing? In: Michel, Sonya and Rianne Mahon (eds.): Child care policy at the crossroads. Gender and welfare state restructuring. Routledge: New York - London, 219-238.

Rostgaard, Tine, Mogens N. Christoffersen, and Hanne Weise (1999): Parental leave in Denmark. In: Moss, Peter and Fred Deven (eds.): Parental leave: Progress or pitfall? Research and policy issues in Europe. NIDI/CBGS Publications 35: Brussels, 25-44.

Rønsen, Marit (2001): Market work, childcare and the division of household labour. Adaptations of Norwegian mothers before and after the cash-for-care reform. Reports 2001/13, Statistics Norway.

Rønsen, Marit (1999): Impacts on fertility and female employment of parental leave programs. Evidence from three Nordic countries. Paper presented at the European Population Conference, The Hague, Netherlands, 30 August - 3 September 1999.

Rønsen, Marit and Marianne Sundström (1999): Public policies and the employment dynamics among new mothers - A comparison of Finland, Norway, and Sweden. Statistics Norway, Division for social and demographic research, Discussion Paper 263, November.

Rønsen, Marit and Marianne Sundström (1997): The choice between full-time and part-time work for Norwegian and Swedish mothers. In: Persson, Inga and Christina Jonung (eds.): Economics of the family and family policies. Routledge: London, 159-177.

Rønsen, Marit and Marianne Sundström (1996): Maternal employment in Scandinavia. A comparison of the after-birth employment activity of Norwegian and Swedish women. In: Journal of Population Economics 9, 267-281.

Ruhm, Christopher J. (1998): The economic consequences of parental leave mandates: Lessons from Europe. In: Quarterly Journal of Economics, 285-317.

Ruhm, Christopher J. and Jacqueline L. Teague (1997): Parental leave policies in Europe and North America. In: Blau, Francine D. and Ronald C. Ehrenberg (eds.): Gender and family issues in the workplace. Russell Sage Foundation: New York, 133-165.

Sainsbury, Diane (2001): Gender and the making of welfare states: Norway and Sweden. In: Social Politics 8/1, 113-143.

Sainsbury, Diane (1999a): Gender, policy regimes, and politics. In: Sainsbury, Diane (ed.): Gender and welfare state regimes. Oxford University Press: Oxford, 245-275.

Sainsbury, Diane (ed.) (1999b): Gender and welfare state regimes. Oxford University Press: Oxford.

Sainsbury, Diane (1994): Gendering welfare states, London: Sage Publications.

Sainsbury, Diane (1993): Dual welfare and sex segregation of access to social benefits: Income maintenance policies in the UK the US, the Netherlands and Sweden. In: Journal of Social Policy 22/1, 69-98.

Saraceno, Chiara (1991): Redefining maternity and paternity: gender, pronatalism and social policies in fascist Italy. In: Bock, Gisela and Pat Thane (eds.): Maternity and gender policies. Women and the rise of the European welfare states 1880s - 1950s. Routledge: London, 196-212.

Saurel-Cubizolles, Marie-Josèphe et al. (1999): Returning to work after childbirth in France, Italy, and Spain. In: European Sociological Review 15/2, 179-194. 
Schmidt, Vivien A. (2000): Values and discourse in the politics of adjustment. In: Scharpf, Fritz W. and Vivien A. Schmidt (eds.): Welfare and work in the open economy. Volume I: From vulnerability to competitiveness. Oxford University Press: Oxford, 229-309.

Simonen, Leila and Anne Kovalainen (1998): Paradoxes of social care cestructuring: The Finnish case. In: Lewis, Jane (ed.): Gender, social care and welfare state restructuring in Europe. Aldershot: Ashgate, 229-255.

Sipilä, Jorma (1995): The right to choose: day care for children or money for parents? In: Social Policy Review 7, 151-169.

Sipilä, Jorma et al (1997): A multitude of universal public services - how and why four Scandinavian countries get their social care service model? In: Sipilä, Jorma (ed.): Social care services: The key to the Scandinavian welfare model. Ashgate: Aldershot, 27-50.

Statistik Austria (2000): Krippen, Kindergärten und Horte (Kindertagesheime). Verlag Österreich: Wien.

Sundström, Marianne and Ann-Zofie Duvander (2002): Gender division of childcare and the sharing of parental leave among new parents in Sweden. In: European Sociological Review 18/4, 433-447.

Sundström, Marianne and Frank P. Stafford (1992): Female labour force participation, fertility and public policy in Sweden. In: European Journal of Population 8/3, 199-215

Szebehely, Marta (1998): Changing divisions of carework: Caring for children and frail elderly people in Sweden. In: Lewis, Jane (ed.): Gender, social care and welfare state restructuring in Europe. Ashgate: Aldershot, 257-283.

The Clearinghouse on international development in child, youth and family policy (Columbia University): http://www.childpolicyintl.org/intpublications.html and http://www.childpolicyintl.org/ecec.html

Trifiletti, Rossana (1998): Restructuring social care in Italy. In: Lewis, Jane (ed.): Gender, social care and welfare state restructuring in Europe. Ashgate: Aldershot, 175-206.

Valiente, Celia (2002): The Value of an educational emphasis: Child care and restructuring in Spain since 1975. In: Michel, Sonya and Rianne Mahon (eds.): Child care policy at the crossroads. Gender and welfare state restructuring. Routledge: London, 57-70.

Van Kersbergen, Kees (1995): Social capitalism: A study of Christian democracy. Routledge: London.

Waerness, Kari (1998): The changing 'welfare mix' in childcare and care for the frail elderly in Norway. In: Lewis, Jane (ed.): Gender, social care and welfare state restructuring in Europe. Ashgate: Aldershot, 207-228.

Watkins, Susan (1990): From local to national communities: The transformation of demographic regimes in Western Europe, 1870 - 1960. In: Population and Development Review 16/2, 241-272.

Wennemo, Irene (1992): The development of family policies: A comparison of family benefits and tax reductions in 18 OECD countries. In: Acta Sociologica 35, 201-217.

Wennemo, Irene (1994): Sharing the costs of children. Studies on the development of family support in the OECD countries. Swedish institute for social research 25. University of Stockholm: Stockholm.

Wikander, Ulla, Alice Kessler-Harris, and Jane Lewis (eds.) (1995): Protecting women. Labor legislation in Europe, the United States, and Australia, 1880 - 1920. University of Illinois Press: Urbana.

Wörister, K (1998a): Statistische Informationen der AK-Wien, Aktuelle Daten. Kammer für Arbeiter und Angestellte für Wien: Wien. 
Wörister, K (1998b): Statistische Informationen der AK-Wien, Aktuelle Daten: Soziale Sicherung, Einkommen, Beschäftigung. Kammer für Arbeiter und Angestellte für Wien: Wien.

Wörister, K. (1997): Statistische Informationen der AK-Wien. Kammer für Arbeiter und Angestellte für Wien: Wien. 
Figure 1:

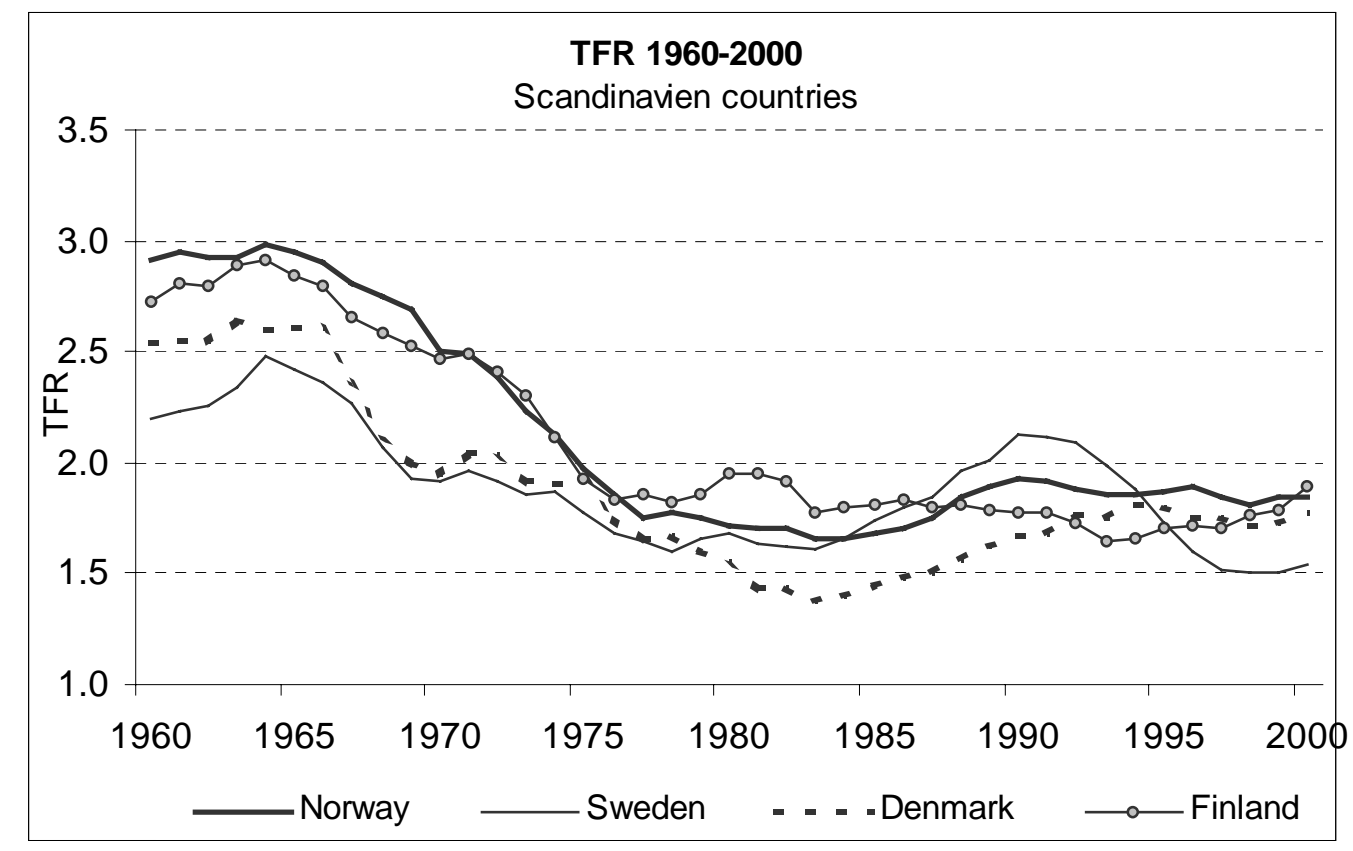

Source: New Cronos

Figure 2:

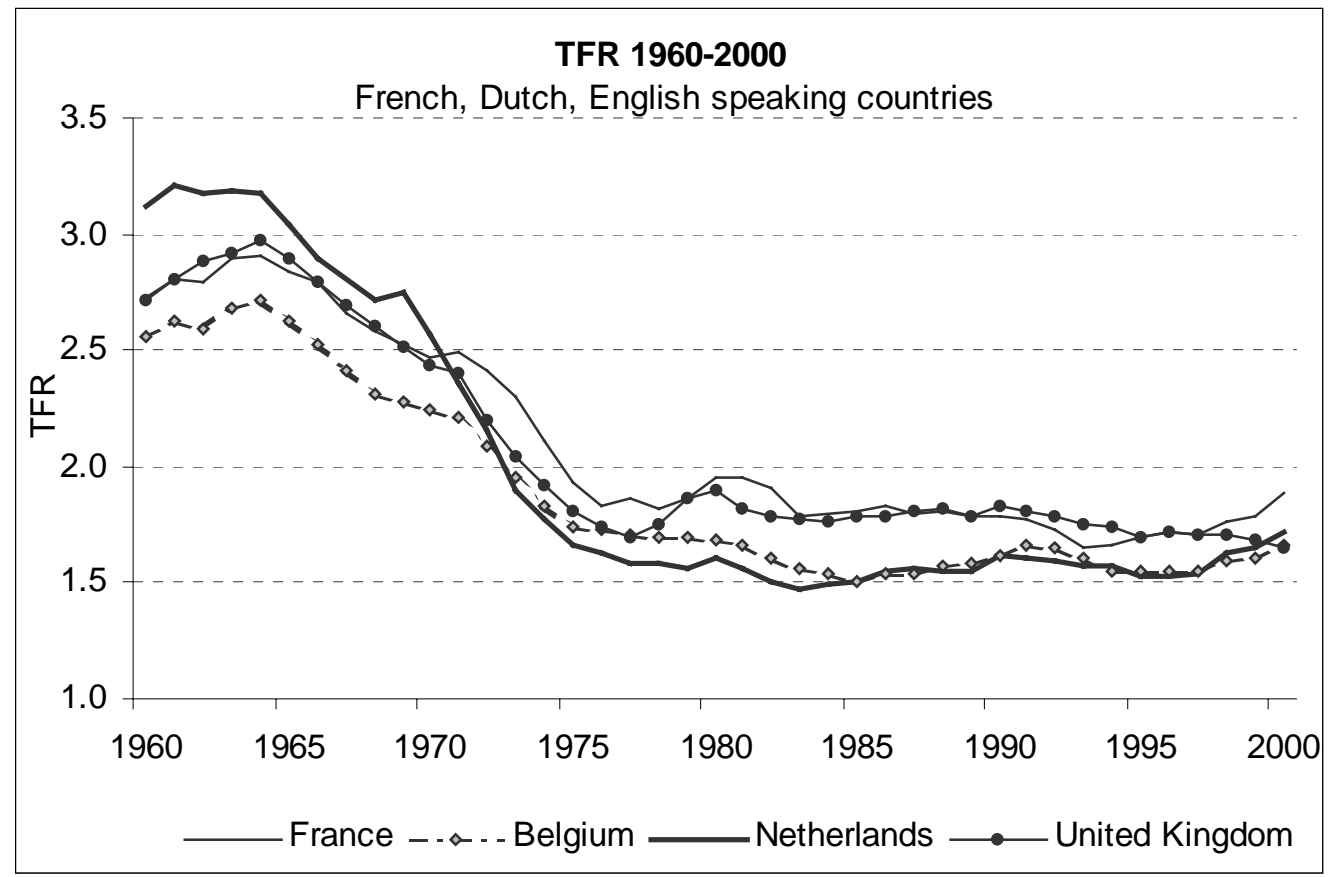

Source: New Cronos 
Figure 3:

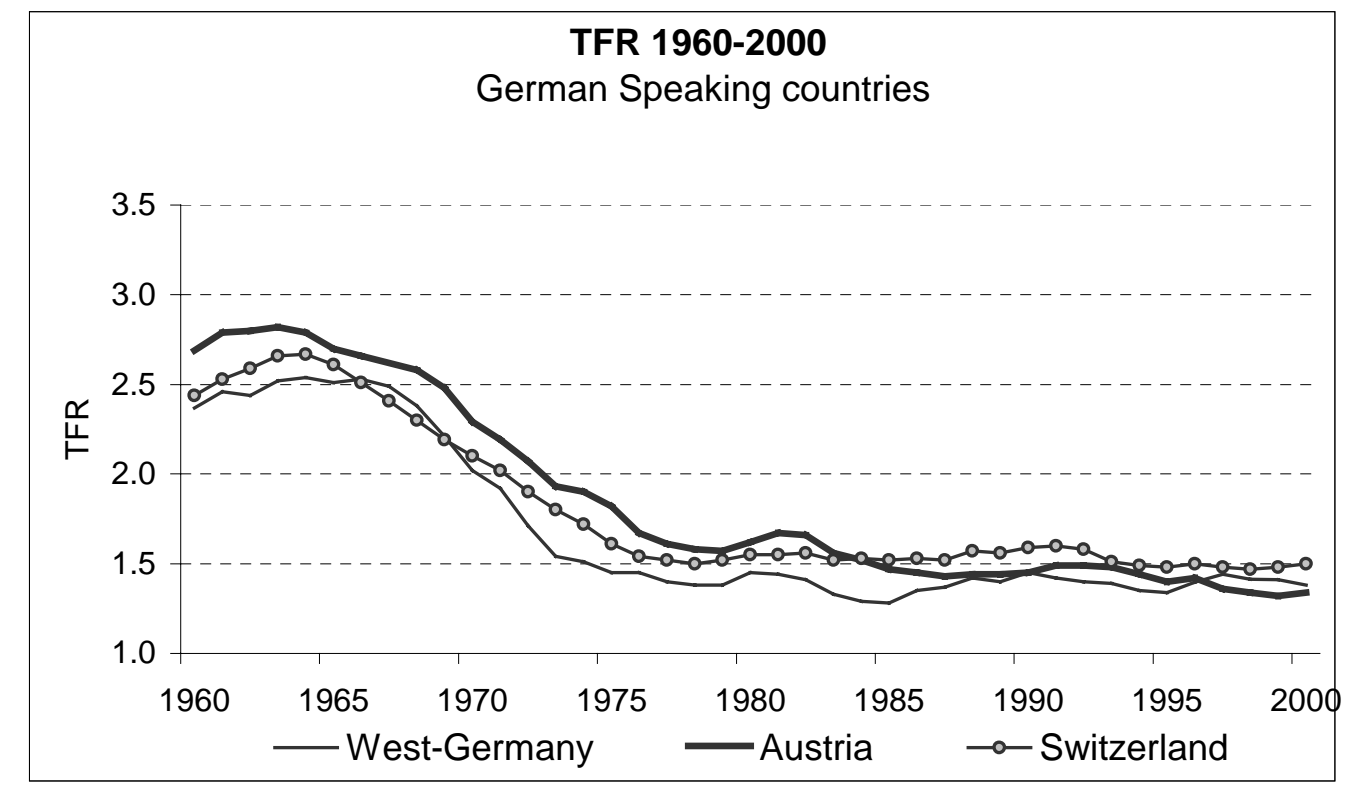

Source: New Cronos

Figure 4:

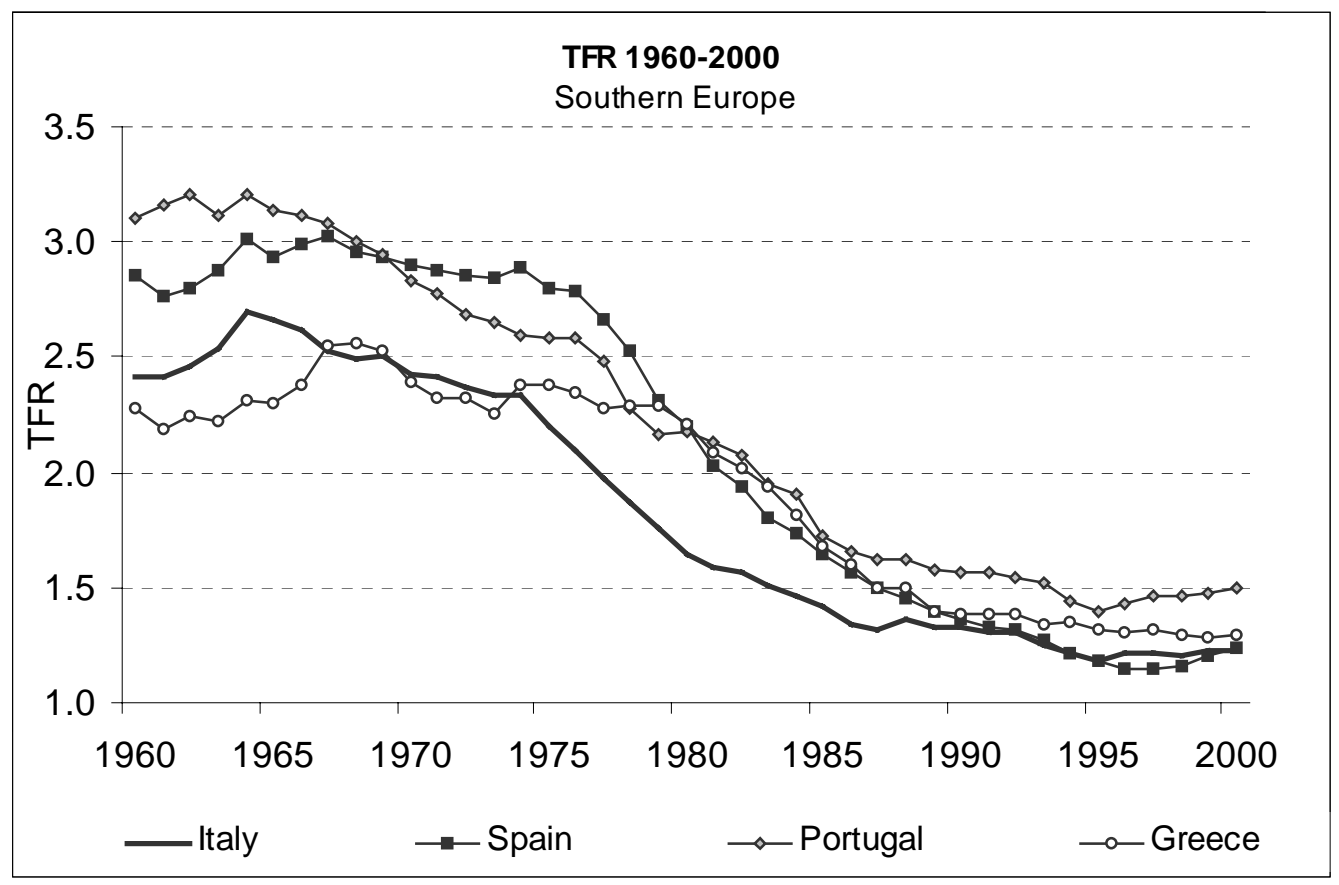

Source: New Cronos 
Figure 5

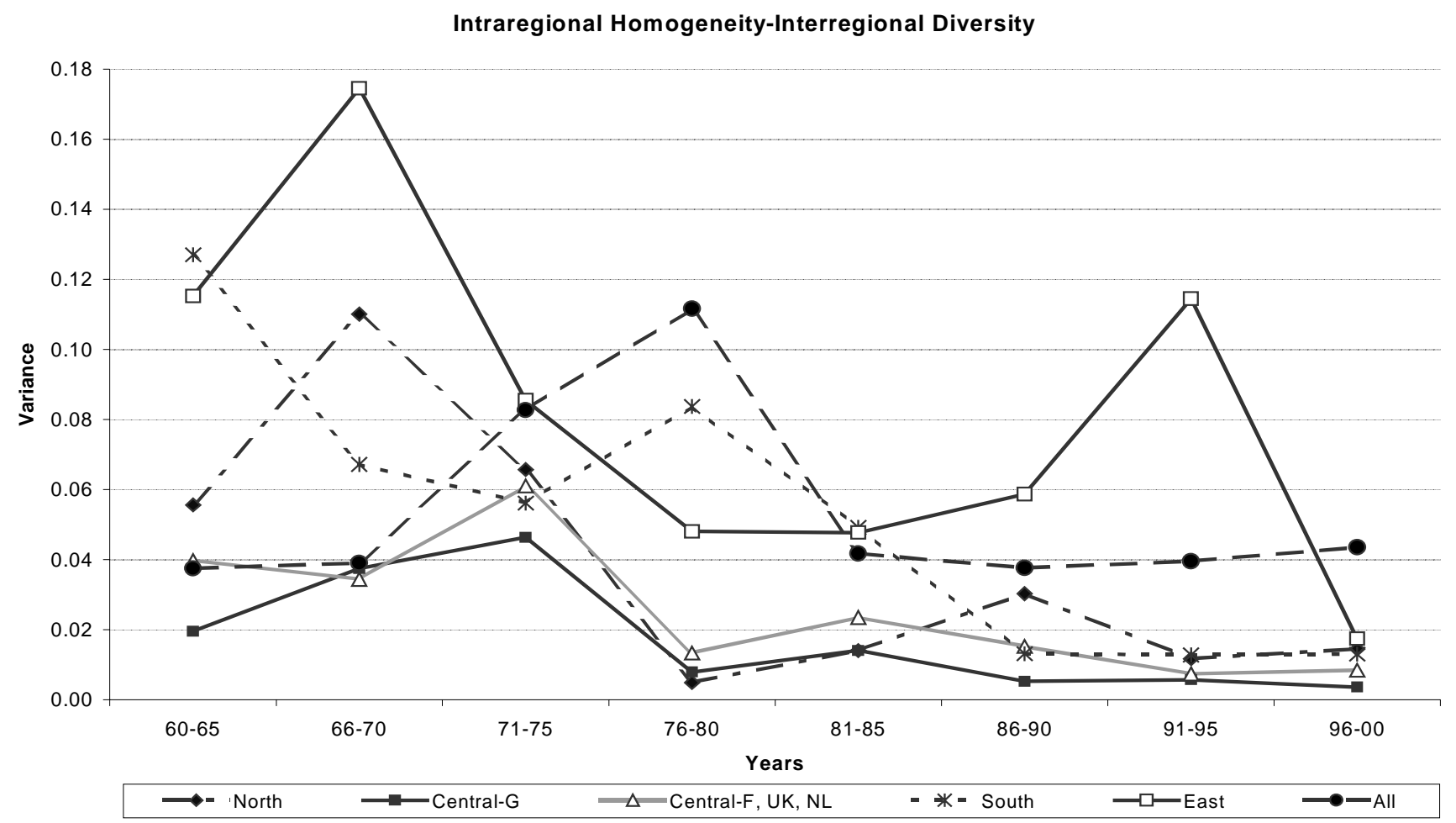


Figure 6:

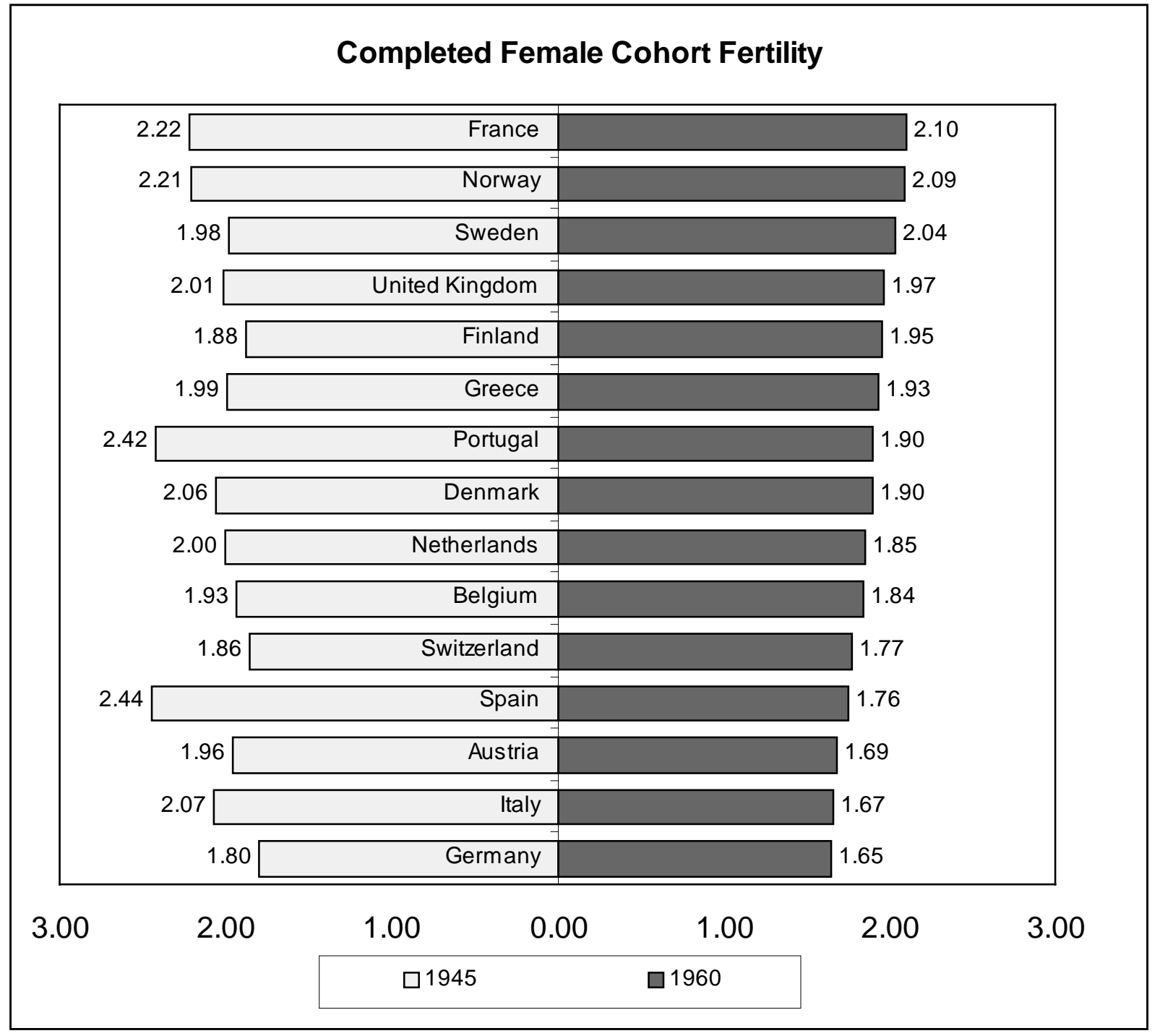


Maternity Provisions in Western Europe, 1999 - 2001

\begin{tabular}{lccc} 
country & duration in weeks & $\begin{array}{c}\text { wage compensation } \\
\text { in } \%\end{array}$ & paternity leave \\
\hline Austria & 16 & 100 & none \\
Belgium & 15 & $\begin{array}{c}82(1 \text { months }) \\
75-60 \text { (rest) }\end{array}$ & $3-4$ days \\
Denmark & 18 & flate rate & 14 days \\
Finland & 17,5 & $43-82$ & $6-18$ days \\
France & $16-26^{2}$ & 84 & 3 days \\
Germany & 14 & 100 & none \\
Greece & 18 & 100 & yes \\
Italy & 20 & 80 & none \\
Netherlands & 16 & 100 & 2 days \\
Norway & 9 & 100 & 2 weeks \\
Portugal & 17,1 & 100 & 5 days \\
Spain & 16 & 100 & 2 days \\
Sweden & 8,5 & 80 & 10 days \\
United Kingdom & 18 & 90 (6 weeks) & none \\
& & flate rate (rest) & \\
\hline
\end{tabular}

Notes: italics: Maternity leave is part of parental leave; the figures given list the weeks reserved to the mother.

1 equivalent to percentage of max. unemployment benefit

${ }^{2} 26$ weeks for third and subsequent child

${ }^{3}$ Statutory paternal leave is unpaid.

Sources: MISSOC 2001 and 2002; Leira 2002; OECD Employment Outlook 2001. 
Maternity Provisions in Western Europe, 1999 - 2001

\begin{tabular}{lccc} 
country & duration in weeks & $\begin{array}{c}\text { wage compensation } \\
\text { in } \%\end{array}$ & paternity leave \\
\hline Greece & 18 & 100 & yes \\
Italy & 20 & 80 & none \\
Denmark & 18 & flate rate & 14 days \\
United Kingdom & 18 & $90(6$ weeks) & none \\
& & flate rate (rest) & $6-18$ days \\
Finland & 17,5 & $43-82$ & 5 days \\
Portugal & 17,1 & 100 & 3 days \\
France & $16-26^{2}$ & 84 & 2 days \\
Netherlands & 16 & 100 & 2 days \\
Spain & 16 & 100 & none \\
Austria & 16 & 100 & $3-4$ days \\
Belgium & 15 & $82(1$ months $)$ & none \\
& & $75-60$ (rest) & 2 weeks \\
Germany & 14 & 100 & 10 days \\
Norway & 9 & 100 & \\
Sweden & 8,5 & 80 &
\end{tabular}

Notes: italics: Maternity leave is part of parental leave; the figures given list the weeks reserved to the mother.

${ }^{1}$ equivalent to percentage of max. unemployment benefit

${ }^{2} 26$ weeks for third and subsequent child

${ }^{3}$ Statutory paternal leave is unpaid.

Sources: MISSOC 2001 and 2002; Leira 2002; OECD Employment Outlook 2001. 
Parental Leave in Western Europe (1999-2002)

\begin{tabular}{|c|c|c|c|c|c|}
\hline Country & Duration & Benefit & Max. age of child (year) & Part-time & Father \\
\hline Austria & 2 years & $\begin{array}{l}\text { flat rate ( } 30 \text { months }+6 \\
\text { months for father) }\end{array}$ & $\begin{array}{l}3 ; 3 \text { months unpaid } \\
\text { until child is } 7\end{array}$ & yes & 6 months 'use or lose' \\
\hline Belgium & $\begin{array}{l}3 \text { months }+ \text { career } \\
\text { break for } 5 \text { years }\end{array}$ & flat rate & $4 ; 10$ public sector & yes & yes \\
\hline Denmark $^{1}$ & $\begin{array}{l}10 \text { weeks either parent + } \\
13 \text { weeks each parent, } \\
26 \text { if child is under } 1\end{array}$ & $\begin{array}{l}\text { flate rate (like maternity) } \\
\text { flat rate }(60 \% \text { unemploy- } \\
\text { ment benefit) }\end{array}$ & $\begin{array}{l}1 / 2 \\
8\end{array}$ & $\begin{array}{l}\text { yes } \\
\text { no }\end{array}$ & $\begin{array}{l}\text { yes } \\
\text { yes }\end{array}$ \\
\hline Finland $^{1}$ & $\begin{array}{l}26 \text { weeks + home-care } \\
\text { allowance until child is } 3\end{array}$ & $\begin{array}{l}43 \%-82 \% \\
\text { flat rate + suppl. per child }\end{array}$ & 3 & $\begin{array}{l}\text { yes } \\
\text { yes }\end{array}$ & $\begin{array}{l}\text { yes } \\
\text { yes }\end{array}$ \\
\hline France & 3 years & flat rate if two+ children & 3 & yes & yes \\
\hline Germany & 3 years & $\begin{array}{l}\text { flat rate } 2 \text { years, } \\
\text { means-tested }\end{array}$ & $\begin{array}{l}3 ; 1 \text { year paid } \\
\text { until child is } 8\end{array}$ & yes & yes \\
\hline Greece & 3.5 months each parent & unpaid & 3; 8 public sector & yes & yes \\
\hline Italy & 10 months total & $30 \%$ of monthly earnings & 8 & yes & $\begin{array}{l}\text { yes, plus } 1 \text { month if father } \\
\text { takes } 3 \text { months }\end{array}$ \\
\hline Netherlands & 6 months each parent & unpaid & 8 & yes & yes \\
\hline Norway ${ }^{1}$ & $\begin{array}{l}42 \text { to } 52 \text { weeks } \\
\text { (incl. Maternity leave) } \\
+1 \text { year cash-for-care }\end{array}$ & $\begin{array}{l}100 \% \text { for } 42 \text { weeks } \\
80 \% \text { for } 52 \text { weeks } \\
\text { Flat rate }\end{array}$ & 2 & yes & 1 month 'use of lose' \\
\hline Portugal & $\begin{array}{l}6 \text { months each parent; } 2-3 \text { years } \\
\text { in case of } 3^{\text {rd }}+\text { birth }\end{array}$ & unpaid & 3 & yes & yes \\
\hline Spain & 3 years & unpaid & $\begin{array}{l}3 ; 6 \text { civil servants in } \\
\text { part-time }\end{array}$ & yes & yes \\
\hline Sweden ${ }^{1}$ & $\begin{array}{l}15 \text { months } \\
3 \text { months }\end{array}$ & $\begin{array}{l}80 \% \text { ( } 1 \text { year; flat rate rest) } \\
\text { unpaid }\end{array}$ & 8 & yes & 1 month 'use of lose' \\
\hline United Kingdom & 13 weeks each parent & unpaid & 5 & yes & yes \\
\hline
\end{tabular}


${ }^{1}$ Only those parts of the parental leave that can be taken by either the mother or the father.

Sources: Moss and Deven 1999; OECD 2001; The Clearinghouse on International Child, Youth and Family Policies at Columbia University; Leira 2002 


\section{Children in publicly funded childcare in Europe, 1993/1994 and 1998/2000}

\begin{tabular}{|c|c|c|c|c|c|c|c|}
\hline \multirow[t]{2}{*}{ Country } & \multicolumn{2}{|c|}{$\begin{array}{l}\text { Children }(0-<3) \text { in } \\
\text { publicly funded } \\
\text { childcare }\end{array}$} & \multirow[t]{2}{*}{$\begin{array}{l}\text { Guaranteed } \\
\text { childcare } \\
(0-<3)\end{array}$} & \multicolumn{2}{|c|}{$\begin{array}{l}\text { Children (3-6) in } \\
\text { publicly funded } \\
\text { childcare }\end{array}$} & \multirow[t]{2}{*}{$\begin{array}{l}\text { Guaranteed } \\
\text { childcare } \\
(3-6)\end{array}$} & \multirow{2}{*}{$\begin{array}{c}\text { Children (6-10) in } \\
\text { publicly funded } \\
\text { after-school care } \\
1993 / 1994\end{array}$} \\
\hline & $1993 / 1994$ & $1998 / 2000$ & & $1993 / 1994$ & $1998 / 2000$ & & \\
\hline Austria & 3 & 4 & no & 75 & 79 & no & 6 \\
\hline Belgium & 30 & 30 & $>2,5$ & 95 & 97 & yes & \\
\hline Denmark & 48 & 64 & yes & 82 & 91 & yes & 80 \\
\hline Finland & 32 & 22 & yes & 59 & 66 & yes & 65 \\
\hline France & 23 & 29 & $>2$ & 99 & 99 & yes & 65 \\
\hline $\begin{array}{l}\text { Germany } \\
\text { (united) }\end{array}$ & 2 & 10 & no & 85 & 78 & yes & \\
\hline Germany West & 2 & 3 & & 85 & 87 & yes & 5 \\
\hline Germany East & 41 & 36 & & 117 & 111 & yes & 34 \\
\hline Greece & 3 & 3 & & 70 & 70 & & \\
\hline Italy & 6 & 6 & no & 91 & 95 & yes & 7 \\
\hline Netherlands & 8 & 6 & no & 71 & 98 & $>4$ & 5 \\
\hline Norway & 31 & 40 & no & 72 & 80 & no & 31 \\
\hline Portugal & 12 & 12 & & 48 & 75 & $>5$ & 10 \\
\hline Spain & 2 & 5 & & 84 & 84 & & \\
\hline Sweden & 33 & 48 & $>18 \mathrm{mo}$ & 72 & 80 & yes & 64 \\
\hline United Kingdom & 2 & $34(1)$ & no & 60 & $60(1)$ & yes & 5 \\
\hline
\end{tabular}

(1) England only

Sources: Daly 2000; Gornick, Meyers, and Ross 1977; OECD 2001a; OECD 2001b. 
Child benefits in Western Europe 2000-2002

\begin{tabular}{|c|c|c|c|}
\hline & basic principle & $\begin{array}{l}\text { by number of } \\
\text { children }\end{array}$ & by age \\
\hline Austria & universal & yes & yes \\
\hline Belgium & employment & yes & yes \\
\hline Denmark & universal & no & yes \\
\hline Finland & universal & yes & no \\
\hline \multirow[t]{2}{*}{ France } & universal & & \\
\hline & 2nd +children & yes & yes \\
\hline Germany & universal & yes & no \\
\hline Greece & $\begin{array}{l}\text { employment, income } \\
\text { related }\end{array}$ & yes & no \\
\hline Italy & $\begin{array}{l}\text { employment, income } \\
\text { related }\end{array}$ & yes (1) & \\
\hline Netherlands & universal & yes (2) & $\begin{array}{l}\text { yes (2) } \\
\text { yes }\end{array}$ \\
\hline Norway & universal & no & yes (3) \\
\hline Portugal & $\begin{array}{l}\text { employment, income } \\
\text { related }\end{array}$ & yes & yes \\
\hline Spain & $\begin{array}{l}\text { Employment, income } \\
\text { related }\end{array}$ & no & no \\
\hline Sweden & universal & yes & no \\
\hline United Kingdom & universal & yes & no \\
\hline
\end{tabular}
(1) by members of household
(2) for children born before 1995
(3) infant supplement for each child aged 1 to 3
Source: MISSOC 2001, 2002 